\title{
TNF- $\alpha$ Regulates Natriuretic Peptides and Aquaporins in Human Bronchial Epithelial Cells BEAS-2B
}

\author{
Letizia Mezzasoma, ${ }^{1}$ Lucio Cagini, ${ }^{2}$ Cinzia Antognelli, ${ }^{1}$ Francesco Puma, \\ Eugenio Pacifico, ${ }^{3}$ and Vincenzo Nicola Talesa ${ }^{1}$ \\ ${ }^{1}$ Department of Experimental Medicine and Biochemical Sciences, University of Perugia, Polo Unico Sant'Andrea delle Fratte, \\ 06156 Perugia, Italy \\ ${ }^{2}$ Thoracic Surgery Unit, Ospedale S. Maria della Misericordia, University of Perugia, S. Andrea delle Fratte, 06156 Perugia, Italy \\ ${ }^{3}$ Clinical Pathology and Hematology Unit, Ospedale S. Maria della Misericordia of Perugia, S. Andrea delle Fratte, 06156 Perugia, Italy
}

Correspondence should be addressed to Vincenzo Nicola Talesa; vincenzo.talesa@unipg.it

Received 15 May 2013; Revised 26 August 2013; Accepted 7 October 2013

Academic Editor: Yong Jiang

Copyright (C) 2013 Letizia Mezzasoma et al. This is an open access article distributed under the Creative Commons Attribution License, which permits unrestricted use, distribution, and reproduction in any medium, provided the original work is properly cited.

\begin{abstract}
Postoperative-fluid retention is a severe complication frequently reported in patients undergoing major surgical procedures. The complex network of molecules involved in such a severe surgery-induced condition remains poorly understood. Inflammation has been proposed among the various causes of fluid retention. Since TNF- $\alpha$ is one of the main proinflammatory cytokine initially released after major surgery, it is reasonable to assume its involvement in fluid overload. Here, we showed that TNF- $\alpha$ selectively regulates key molecules involved in fluids balance, such as natriuretic peptides (NPs) and aquaporins, in human bronchial epithelial cells BEAS-2B. In particular, we found that TNF- $\alpha$ induced a decrease of arial natriuretic peptide, natriuretic peptide receptor-1, aquaporin- 1 and aquaporin- 5 and an increase of brain natriuretic peptide with a different involvement of nuclear factor- $\kappa \mathrm{B}$ and mitogen-activated protein kinases signaling pathway activation. Moreover, the observed changes in NPs expression, demonstrate inflammation as an additional cause of brain natriuretic peptide elevation, adding an important piece of information in the novel area of study regarding NPs and inflammation. Finally, we suggest that inflammation is one of the mechanisms of Aquaporin1 and aquaporin-5 expression regulation. Therefore, in this exploratory study, we speculate that TNF- $\alpha$ might be involved in postoperative-fluid retention related to major surgery.
\end{abstract}

\section{Introduction}

Weight gain with edema formation is frequently reported in patients undergoing major surgical procedures, with an incidence as high as $40 \%$ [1]. Postoperative weight gain and fluid overload have been associated with poor survival [2] and complications $[3,4]$. The causes of fluid retention are various, and not completely clear. One of them could be related to the systemic response induced by surgical stress and operative trauma, regulated by a complex network of endocrine, neuronal, and immunological mechanisms [57]. Such surgery-induced reaction leads to an early hyperinflammatory status that is essential for tissue repair and host defense [5]. Cytokines are thought to play a pivotal role in the pathogenesis of surgical trauma. They have local effects of mediating and maintaining the inflammatory response to tissue injury and also initiate some of the systemic changes which occur [8-10]. After major surgery, TNF- $\alpha$ is one of the main proinflammatory cytokines initially released in the damaged tissue where it stimulates the production and release of more cytokines, responsible for inducing the systemic changes known as the acute phase response $[5,10]$. Therefore, it is reasonable to assume TNF- $\alpha$ involvement among the various causes of fluid retention and thus it would be very important to understand the mechanisms underlying its involvement in this area.

In a recent study, patients undergoing pulmonary lobectomy, showed a significant weight gain, correlated with fluid retention, and an early rise in the plasma concentrations of brain natriuretic peptide (BNP), a member of the natriuretic 
peptides (NPs) family [11]. In particular, a significant weight gain was found to be correlated with large volumes of fluids accumulation on the postoperative day 2 , despite a negative intraoperative fluid balance and peroperative strict fluid restriction [11]. Moreover, the patients, none of whom developed signs or symptoms of heart failure during the postoperative period, showed, immediately after surgery (on day 1) a significant increase in BNP plasma concentration [11]. NPs are hormone/paracrine factors that are released by the heart in response to myocardial stretch and overload, modulating body fluid homeostasis $[12,13]$. BNP, secreted from the cardiac ventricles, and atrial natriuretic peptide (ANP), secreted from the cardiac atria, activate the same transmembrane guanylyl cyclase-A/natriuretic peptide receptor-A (NPR-A or NPR-1) [14-17]. In addition to vasodilation, cardiovascular homeostasis, sodium excretion, and inhibition of aldosterone secretion, it is becoming increasingly recognized that NPs possess a much broader range of biological activities, including effects on endothelial function and inflammation [18, 19]. The genetic expression and secretion of ANP and BNP have been studied mainly in the context of cardiac diseases associated with neuroendocrine and hemodynamic changes $[12,13,20]$; however it has been pointed out that changes in $\mathrm{BNP}$ also occur in a context of an acute inflammatory process $[19,21-24]$.

Another family of proteins, aquaporins (AQPs), is deeply involved in the physiological response to change of fluid volume and osmolarity $[25,26]$. AQPs are widely distributed in various tissues throughout the body and facilitate osmotically driven water transport across cell membranes [25-27]. Recently, AQPs involvement in edema development has been pointed out. In particular, it has been shown that AQP4 is an essential mediator in the formation and resorption of edema fluid from brain parenchyma [28] and that AQP1 and AQP5 might play an important role in lung edema [29]. In addition, AQP1 and AQP5 expression is decreased in lung inflammation [30, 31].

The aim of our work was to investigate the potential involvement of TNF- $\alpha$ in the regulation of ANP, BNP, and their receptor NPR-1, as well as AQP1 and AQP5, key molecules involved in body fluid homeostasis. In order to exclude any hemodynamic change able to modulate NPs expression, we carried out an in vitro study, in human bronchial epithelial cells BEAS-2B.

\section{Materials and Methods}

2.1. Reagents. Human TNF- $\alpha$ was obtained from ImmunoTools GmbH (Friesoythe, Germany). The Nuclear Factor$\kappa \mathrm{B}(\mathrm{NF}-\kappa \mathrm{B})$ inhibitors, BAY 11-7082 and QNZ, as well as the p38 mitogen-activated protein kinases (p38 MAPK) inhibitor SB 203580, the c-Jun N-terminal kinases $1 / 2$ (JNK 1/2) inhibitor SP 600125, and the extracellular-signalregulated kinases 1/2 (ERK 1/2) inhibitor U-0126, were obtained from Santa Cruz Biotechnology, Inc. (Heidelberg, Germany) and were dissolved in dimethyl sulfoxide (DMSO). Human BNP was obtained from Phoenix Europe GmbH (Karlsruhe, Germany). Dexamethasone (DEX) was from Sigma-Aldrich (Milan, Italy). Rabbit polyclonal antibodies
(Abs) against ANP, NPR-1, AQP1, and AQP5 as well as the mouse monoclonal $\mathrm{Ab}$ against $\beta$-actin and the appropriate HRP-conjugated secondary Abs, were purchased from Santa Cruz Biotechnology, Inc. (Heidelberg, Germany). Rabbit monoclonal Abs against Phospho-I $\kappa \mathrm{B}-\alpha$ and Phospho-p38 MAPK were purchased from Cell Signaling Technology, Inc. (Danvers, MA).

2.2. Cell Culture and Drug Treatments. Human bronchial epithelial cell line BEAS-2B was purchased from American Type Culture Collection (ATCC) and was routinely maintained at $37^{\circ} \mathrm{C}$ in $5 \% \mathrm{CO}_{2}$ in RPMI 1640 , supplemented with $10 \%$ heat inactivated $\left(1 \mathrm{~h}\right.$ at $\left.56^{\circ} \mathrm{C}\right)$ fetal calf serum, 1X Lglutamine, $1 \mathrm{mM}$ sodium pyruvate, $1 \mathrm{X}$ nonessential amino acids, 100 units $/ \mathrm{mL}$ of penicillin, and $0.1 \mathrm{mg} / \mathrm{mL}$ of streptomycin (Invitrogen, Milan, Italy). Forty-eight hours before study, cells were seeded onto six-well culture dishes at 300.000 cells/well. TNF- $\alpha$ was dissolved in distilled water and used at the concentrations of 10,20 , and $40 \mathrm{ng} / \mathrm{mL}$ for $24 \mathrm{~h}$. Inhibitors, BAY 11-7082, QNZ, SB 203580, SP 600125, and U0126 were dissolved in $0.5 \%$ DMSO. The anti-inflammatory glucocorticoid DEX was dissolved in $0.1 \%$ methanol. In independent experiments, BAY 11-7082, QNZ, SB 203580, SP 600125 , and U-0126, and DEX were added to cells $60 \mathrm{~min}$ before TNF- $\alpha$ administration at the concentration of $1 \mu \mathrm{M}$ for BAY 11-7082 or DEX and $10 \mu \mathrm{M}$ for QNZ, SB 203580, SP 600125 , or U-0126. DMSO or methanol final concentrations in each assay were $0.005 \%$ and $0.001 \%$, respectively. Control cells with DMSO or methanol did not show any significant difference respect to control cells in RPMI 1640 medium; therefore all the relative treatments were compared to these latter controls.

2.3. Cell Viability. The effects of TNF- $\alpha$, BAY 11-7082, QNZ, SB 203580, SP 600125, U-0126, DEX, and BNP treatments were measured with a standard trypan blue uptake assay. Cell cultures were also examined morphologically via light microscopy.

2.4. RNA Isolation and cDNA Synthesis. Total cellular RNA was isolated using TRIzol Reagent (Invitrogen, Milan, Italy) according to the manufacturer's instructions and $1 \mu \mathrm{g}$ was reverse transcribed using the RevertAid H Minus First Strand cDNA Synthesis Kit (Fermentas, Hanover, MD) and random primers System (Invitrogen, Milan, Italy), according to the manufacturer's instructions.

2.5. Quantitative Real Time SYBR Green PCR Analysis. We employed quantitative Real Time SYBR Green PCR analysis (qRT-PCR) on Mx3000P QPCR Systems (Agilent Technologies, Milan, Italy) to evaluate the expression of ANP (NM_006172), BNP (NM_002521), NPR-1 (NM_000906), AQP1(NM_198098), and AQP5 (NM_001651) versus ACTB (NM_001101). The sequences of oligonucleotide primers used for qRT-PCR and the thermal cycling conditions are summarized in Table 1. All primers were designed using Beacon Designer 4 software (Stratagene, La Jolla, CA), starting from published sequences data supplied by the NCBI database. 
TABLE 1: Primer sequences, primer concentrations, and qRT-PCR cycling conditions.

\begin{tabular}{|c|c|c|c|}
\hline Gene & Primer sequences & Primer concentrations & qRT-PCR cycling conditions \\
\hline \multirow{2}{*}{ ANP } & F: $5^{\prime}$-tcagcccagcccagagag- $3^{\prime}$ & $200 \mathrm{nM}$ & 1 cycle at $95^{\circ} \mathrm{C}$ for $10 \mathrm{~min} ; 40$ cycles at $95^{\circ} \mathrm{C}$ for $1 \mathrm{~min}$, \\
\hline & R: $5^{\prime}$-gctccaatcctgtccatcctg- $3^{\prime}$ & $200 \mathrm{nM}$ & $60^{\circ} \mathrm{C}$ for $30 \mathrm{sec}$ and $72^{\circ} \mathrm{C}$ for $30 \mathrm{sec}$. \\
\hline \multirow{2}{*}{$\mathrm{BNP}$} & F: $5^{\prime}$-gagggcaggtgggaagcaaac- $3^{\prime}$ & $200 \mathrm{nM}$ & 1 cycle at $95^{\circ} \mathrm{C}$ for $10 \mathrm{~min}, 40$ cycles at $95^{\circ} \mathrm{C}$ for $1 \mathrm{~min}$, \\
\hline & R: $5^{\prime}$-gcaagaagagcaggagcaggag- $3^{\prime}$ & $200 \mathrm{nM}$ & $60^{\circ} \mathrm{C}$ for $30 \mathrm{sec}$ and $72^{\circ} \mathrm{C}$ for $30 \mathrm{sec}$. \\
\hline \multirow{2}{*}{ NPR-1 } & F: $5^{\prime}$-ccctggaggtgctggctttgg- $3^{\prime}$ & $200 \mathrm{nM}$ & 1 cycle at $95^{\circ} \mathrm{C}$ for $10 \mathrm{~min} ; 40$ cycles at $95^{\circ} \mathrm{C}$ for $1 \mathrm{~min}$, \\
\hline & R: $5^{\prime}$-ctctcaaggctactgggctcaacg- $3^{\prime}$ & $200 \mathrm{nM}$ & $59^{\circ} \mathrm{C}$ for $30 \mathrm{sec}$ and $72^{\circ} \mathrm{C}$ for $30 \mathrm{sec}$ \\
\hline \multirow{2}{*}{ AQP1 } & F: $5^{\prime}$-ttggacacctcctggctattgact- $3^{\prime}$ & $400 \mathrm{nM}$ & 1 cycle at $95^{\circ} \mathrm{C}$ for $10 \mathrm{~min} ; 40$ cycles at $95^{\circ} \mathrm{C}$ for $1 \mathrm{~min}$, \\
\hline & R: $5^{\prime}$-ccagtggttgctgaagttgtgtgt- $3^{\prime}$ & $400 \mathrm{nM}$ & $60^{\circ} \mathrm{C}$ for $30 \mathrm{sec}$ and $72^{\circ} \mathrm{C}$ for $30 \mathrm{sec}$ \\
\hline \multirow{2}{*}{ AQP5 } & F: $5^{\prime}$-cgctcaacaacaacacaacgc- $3^{\prime}$ & $200 \mathrm{nM}$ & 1 cycle at $95^{\circ} \mathrm{C}$ for $10 \mathrm{~min} ; 40$ cycles at $95^{\circ} \mathrm{C}$ for $1 \mathrm{~min}$, \\
\hline & R: $5^{\prime}$-ccagtgaagtagattccgacaagg- $3^{\prime}$ & $200 \mathrm{nM}$ & $59^{\circ} \mathrm{C}$ for $30 \mathrm{sec}$ and $72^{\circ} \mathrm{C}$ for $30 \mathrm{sec}$ \\
\hline \multirow{2}{*}{ ACTB } & F: $5^{\prime}$-cactcttccagccttccttcc- $3^{\prime}$ & $600 \mathrm{nM}$ & 1 cycle at $95^{\circ} \mathrm{C}$ for $10 \mathrm{~min} ; 40$ cycles at $95^{\circ} \mathrm{C}$ for $1 \mathrm{~min}$, \\
\hline & R: $5^{\prime}$-acagcactgtgttggcgtac- $3^{\prime}$ & $600 \mathrm{nM}$ & $59^{\circ} \mathrm{C}$ or $60^{\circ} \mathrm{C}$ for $30 \mathrm{sec}$ and $72^{\circ} \mathrm{C}$ for $30 \mathrm{sec}$. \\
\hline
\end{tabular}

qRT-PCR: quantitative real time polymerase chain reaction; F: forward; R: reverse.

Reactions were performed in a total volume of $25 \mu \mathrm{L}$, containing $250 \mathrm{ng}$ or $500 \mathrm{ng}$ of cDNA, 1X Reagent Brilliant II SYBR Green QPCR Master Mix, and the appropriate concentration of the specific primers (Medical, Milan, Italy). Data for comparative analysis of gene expression were obtained using the $\Delta \Delta \mathrm{Ct}$ method, as described in the ABI Prism 7000 sequence detection system user guide [32]. Agarose gel electrophoretic analysis was used to check the predicted size amplicons for ANP (160 bp), BNP (148 bp), NPR-1 (151bp), AQP1 (98bp), and AQP5 (180 bp).

2.6. Western Blot Analysis. Total protein extracts ( $40 \mu \mathrm{g})$ were separated by $12 \%$ sodium dodecyl sulfate-polyacrylamide gel electrophoresis (SDS-PAGE) and blotted onto a nitrocellulose membrane, using iBlot Dry Blotting System (Invitrogen, Milan, Italy). Nonspecific binding sites were blocked in RotiBlock (Roth $\mathrm{GmbH}$, Karlsruhe, Germany) for $2 \mathrm{~h}$ at room temperature. The membranes were blotted overnight at $4^{\circ} \mathrm{C}$ with a 1:100 dilution of the primary specific Abs and washed with TBST. The antigen-Ab complex was detected by incubation of the membranes for $2 \mathrm{~h}$ at room temperature with the appropriated HRP-conjugated secondary Abs and revealed using the enhanced chemiluminescence (ECL) system by Amersham Pharmacia Biotech (Uppsala, Sweden).

As internal loading controls and for protein expression normalizing purpose, all membranes were subsequently stripped of the first antibody in a stripping buffer $(100 \mathrm{mM}$ 2-ME, 2\% SDS, and $62.5 \mathrm{mM}$ Tris- $\mathrm{HCl}, \mathrm{pH} 6.8$ ) for $30 \mathrm{~min}$ at $50^{\circ} \mathrm{C}$ followed by washings with TBST. The membranes were then reprobed with anti- $\beta$-actin antibody, followed by incubation with HRP-conjugated $\mathrm{Ab}$.

2.7. BNP Protein Concentration in Culture Medium. BNP protein concentration was measured in culture medium using the chemiluminescent enzyme immunoassay kit TRIAGE BNP (Biosite Incorporated, San Diego, USA). The minimum quantity of human BNP detectable with this system is $1.0 \mathrm{pg} / \mathrm{mL}$. The intraassay and the interassay coefficients of variations were $3.1 \%$ and $4.5 \%$, respectively.
2.8. Statistical Analysis. Results were expressed as means \pm $\mathrm{SD}$ of three independent experiments. The statistical significance of differences between treated and untreated cells was assessed by Student's $t$-test. Differences between groups were considered significant when $P<0.05$.

\section{Results}

3.1. TNF- $\alpha$ Selectively Modulates ANP, BNP, and Their Receptor NPR-1 Expression in BEAS-2B Cells. We firstly demonstrated that BEAS-2B cell line expresses ANP, BNP, NPR-1, AQP1, and AQP5. By qRT-PCR analysis, fragments of the predicted molecular size were generated (Figure 1). To determine whether the expression of ANP, BNP, and NPR-1 was affected by TNF- $\alpha$, BEAS-2B cells were treated with 10, 20, or $40 \mathrm{ng} / \mathrm{mL}$ TNF- $\alpha$ for $24 \mathrm{~h}$. ANP mRNA was significantly decreased, about 75\% $(P<0.0001)$ and about 40\% $(P<$ 0.05) of control, after treatment with 10 and $20 \mathrm{ng} / \mathrm{mL}$ TNF$\alpha$, respectively. Forty ng/mL TNF- $\alpha$ induced an upregulation (about 20\% of control) of ANP expression, even though not statistically significant $(P>0.05)$ (Figure $2(\mathrm{a})$ ). A similar trend was also observed at protein level (Figure 2(b)). BNP mRNA expression was significantly $(P<0.01)$ increased ( $62 \%$ of control) since $10 \mathrm{ng} / \mathrm{mL}$ TNF- $\alpha$ treatment, maximum stimulation ( $80 \%$ of control) being obtained with $40 \mathrm{ng} / \mathrm{mL}$ $(P<0.0001)$ (Figure 2(c)). Treatment with TNF- $\alpha$, at the above described concentrations, also increased BNP protein secretion in culture medium $(P<0.01)$ (Figure $2(\mathrm{~d})$ ). NPR-1 gene expression level was dramatically decreased (70$80 \%$ of control) after TNF- $\alpha$ exposure at all the used doses $(P<0.001)$ (Figure $2(\mathrm{e}))$, paralleled by a decrease of protein expression (Figure 2(f)).

3.2. NPs and NPR-1 Modulation by TNF- $\alpha$ May Require Activation of $N F-\kappa B$ Signaling Pathway in BEAS-2B Cells. As known, TNF- $\alpha$ regulates numerous genes essential to the inflammatory process, through the activation of multiple signal transduction pathways, including NF- $\kappa \mathrm{B}$ [33]. Therefore, to investigate the possible involvement of NF$\kappa \mathrm{B}$ signaling pathway in TNF- $\alpha$-mediated regulation of NPs 

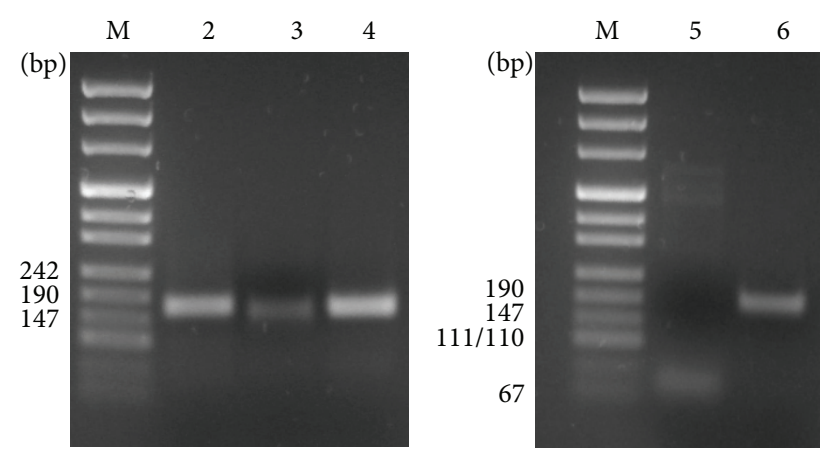

FIGURE 1: Identification of ANP, BNP, NPR-1, AQP1, and AQP5 transcripts in BEAS-2B cells. qReal-Time PCR was performed using gene specific primers for ANP (lane 2), BNP (lane 3), NPR-1 (lane 4), AQP1 (lane 5), sand AQP5 (lane 6) in BEAS-2B cells. Single bands of the predicted molecular size for ANP (160 bp), BNP (148 bp), NPR-1 (151 bp), AQP1 (98 bp), and AQP5 (180 bp) transcripts were detected. Lane M: DNA molecular marker.

and NPR-1, we used the specific NF-kB inhibitor BAY 117082 , that diminishes the activation of NF- $\kappa$ B by preventing phosphorylation of its inhibitory $\mathrm{I} \kappa \mathrm{B}-\alpha$ protein. As shown in Figure 3(a), TNF- $\alpha$-induced downregulation of ANP was completely reverted by BAY 11-7082 at both mRNA and protein level (Figure 3(b)), suggesting that this response requires NF- $\kappa$ B activation pathway. Regarding TNF- $\alpha$-induced BNP upregulation, this was only partially reverted by BAY 11-7082 at mRNA level (Figure 3(c)), while was completely reverted at protein level (Figure 3(d)). Conversely, TNF- $\alpha$-induced decrement in NPR-1 expression was not affected by BAY 117082 either at mRNA or protein level (Figures 3(e) and 3(f)).

Western blot analysis for the $\mathrm{Ser}^{32}$-phosphorylated I $\kappa$ B- $\alpha$ protein proved the biochemistry evidence of the inhibitory action of BAY 11-7082 on NF- $\kappa$ B activity (Figure 3(g)). To further investigate the role of NF- $\kappa \mathrm{B}$ in the modulation of BNP and NPR-1 in BEAS-2B cells after TNF- $\alpha$ treatment, we employed the NF- $\kappa$ B-DNA binding inhibitor QNZ, which prevents free NF- $\kappa \mathrm{B}$ from binding to DNA [34]. The results obtained with such additional inhibitor, confirmed the previous findings obtained with BAY 11-7082. In particular, TNF$\alpha$-induced BNP up-regulation was not reverted by QNZ at mRNA level (Figure 4(a)), while it was completely reverted at protein level (Figure 4(b)). Accordingly, also TNF- $\alpha$-induced decrement of NPR-1 expression was not affected by QNZ, either at mRNA or protein level (Figures 4(c) and 4(d)). Western blot analysis for the $\mathrm{Ser}^{32}$-phosphorylated I $\kappa \mathrm{B}-\alpha$ protein proved the biochemistry evidence of the inhibitory action of QNZ on NF- $\kappa$ B activity (Figure 4(e)).

3.3. BNP and NPR-1 Modulation by TNF- $\alpha$ May Require Activation of MAPKs Signaling Pathway in BEAS-2B Cells. Because TNF- $\alpha$ is able to activate multiple signal transduction pathways, including MAPKs, and because the activation of p38 MAPK and JNK participates in the regulation of inflammatory processes in bronchial epithelial cells $[35,36]$, we then investigated MAPKs pathway involvement in TNF- $\alpha$ modulation of BNP and NPR-1 expression. TNF- $\alpha$-mediated up-regulation of BNP was not affected by SB 203580 or SP 600125, p38 MAPK, and JNK 1/2 inhibitors, respectively, while it was completely reverted by the ERK $1 / 2$ inhibitor U-0126 (Figures 5(a) and 5(b)), suggesting that ERK 1/2 activation pathway is required for BNP TNF- $\alpha$-mediated modulation. Regarding NPR-1, the TNF- $\alpha$-mediated downregulation was completely reverted by the use of all inhibitors (Figures 5(c) and 5(d)). Western blot analysis for the $\mathrm{Thr}^{180} / \mathrm{Thr}^{182}$-phosphorylated form of $\mathrm{p}$-38 MAPK proved the biochemistry evidence of the inhibitory action of $\mathrm{SB}$ 203580 on p38 MAPK activity (Figure 5(e)).

3.4. TNF- $\alpha$ Decreases AQP1 and AQP5 Expression in BEAS $2 B$ Cells. We found that TNF- $\alpha$ induced a dose dependent down-regulation of AQP1 expression $(P<0.01)$ at mRNA (Figure 6(a)) and protein level (Figure 6(b)) and a dramatic decrease in AQP5 gene expression level (about $80 \%$ of control) with all the used doses $(P<0.001)$ (Figure 6(c)), paralleled by a comparable trend at protein level (Figure 6(d)).

3.5. Decreased AQP1 and AQP5 Expression by TNF- $\alpha$ Does Not Require Activation of NF- $\kappa B$ Signaling Pathway in BEAS-2B Cells. To examine a possible involvement of NF- $\kappa$ B in TNF$\alpha$-mediated down-regulation of AQP1 and AQP5, BEAS-2B cells were incubated with BAY 11-7082. Cotreatment of such NF- $\kappa$ B inhibitor with TNF- $\alpha$ resulted in a decrease of AQP1 expression, which was similar to that observed with TNF- $\alpha$ alone (Figures $7(\mathrm{a})$ and $7(\mathrm{~b})$ ), suggesting that the observed response does not require NF- $\kappa \mathrm{B}$ activation. Conversely, cotreatment of BAY 11-7082 with TNF- $\alpha$ affected AQP5 only at protein level (Figures $7(\mathrm{c})$ and $7(\mathrm{~d})$ ).

3.6. BNP Effect on ANP, NPR-1, and AQP1 or AQP5 mRNA Expression in BEAS-2B Cells. In order to determine a possible direct involvement of BNP on the gene expression of ANP, NPR-1 and AQP1 or AQP5, BEAS-2B cells were treated with $0.01 \mathrm{nM}$ BNP. This concentration was previously found to be accumulated in culture medium after $40 \mathrm{ng} / \mathrm{mL}$ TNF- $\alpha$ treatment, the dose that induced the maximum effect on the expression of the studied genes. BNP administration induced a significant $(P<0.05)$ increase $(100 \%$ of control) on ANP mRNA level (Figure 8(a)) and did not affect NPR-1 expression (Figure $8(\mathrm{~b})$ ), while induced a marked decrease $(45 \%$ of control) on AQP1 mRNA level $(P<0.05)$ (Figure 8(c)). A trend in decreasing was also observed for AQP5 gene expression, even though not statistically significant $(P>$ 0.05) (Figure 8(d)).

3.7. Dexamethasone (DEX) Effect on BNP mRNA and Protein Levels in BEAS-2B Cells. In order to study the capability of the anti-inflammatory drug DEX to affect TNF- $\alpha$-mediated up-regulation of BNP mRNA and protein levels, BEAS-2B cells were treated with $1 \mu \mathrm{M}$ DEX. As shown in Figure 9, DEX induced a down-regulation of BNP expression and protein levels, alone or in combination with $40 \mathrm{ng} / \mathrm{mL}$ TNF- $\alpha(P<$ 0.01 ), demonstrating the capability of this glucocorticoid to revert TNF- $\alpha$ effects. 


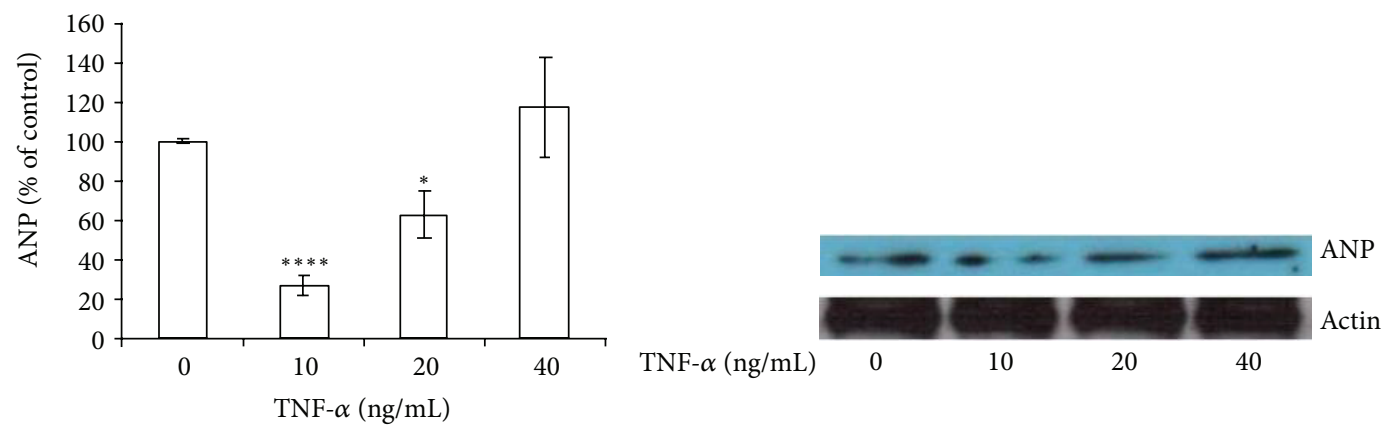

(a)

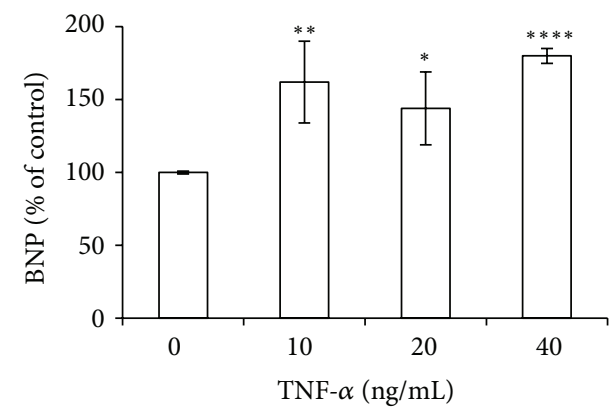

(c)

(e)

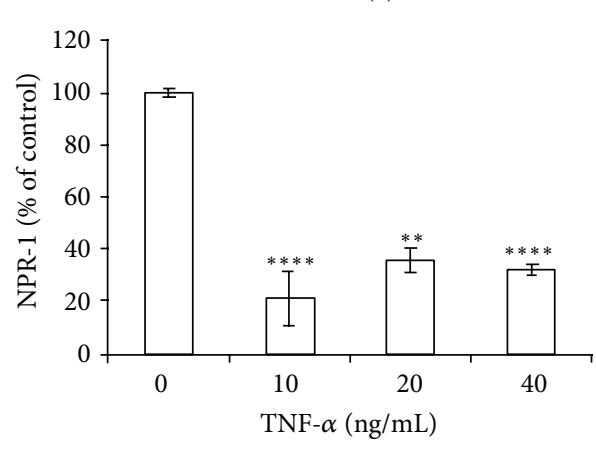

(b)

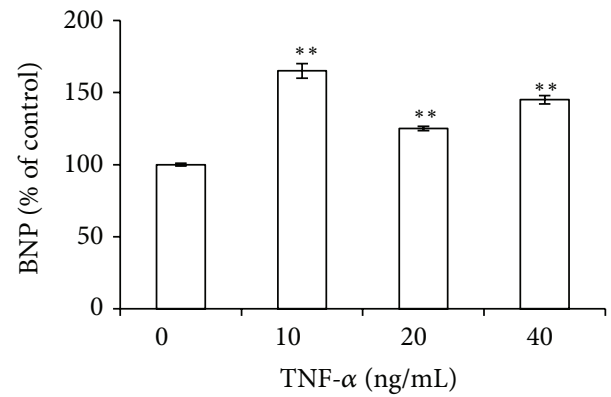

(d)

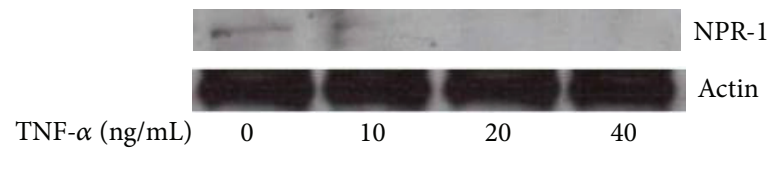

(f)

Figure 2: TNF- $\alpha$ selectively modulates ANP, BNP, and NPR-1 expression. BEAS-2B cells were treated with 10,20 , and $40 \mathrm{ng} / \mathrm{mL}$ TNF- $\alpha$ for 24 h. ((a), (b)) ANP, ((c), (d)) BNP, and ((e), (f)) NPR-1 gene expression at mRNA ((a), (c), and (e)) and protein level ((b), (d), and (f)). Western blots were obtained by using the specific rabbit polyclonal Abs. The blots were stripped of the bound Ab and reprobed with mouse anti- $\beta$-actin, to confirm equal loading. Western blots are representative of three separate experiments. All histograms indicate means \pm SD of three different cultures each one tested in quadruplicate and expressed as percentage of control $\left({ }^{*} P<0.05,{ }^{* *} P<0.01,{ }^{* * *} P<0.001\right.$, and ${ }^{* * * *} P<0.0001$ versus untreated cells).

\section{Discussion}

Postoperative-fluid retention is a severe complication frequently reported in patients undergoing major surgical procedures [1-4]. The complex network of molecules involved in such a severe surgery-induced condition remains poorly understood. After major surgery, TNF- $\alpha$ is one of the main proinflammatory cytokines initially released in the damaged tissue where it stimulates the production and release of more cytokines, responsible for inducing the systemic changes known as the acute phase response $[5,10]$. Therefore, it is reasonable to assume TNF- $\alpha$ involvement among the various causes of fluid retention and very important to understand the mechanisms underlying its involvement in such an ambit.
In the present study we demonstrated, for the first time to our knowledge, that TNF- $\alpha$ modulates the expression of ANP, BNP, NPR-1, AQP1, and AQP5 in human bronchial epithelial cells, BEAS-2B, via different involvement of NF- $\kappa$ B and MAPKs signaling pathway activation. Here, we also provided the first demonstration that human bronchial epithelial cells express ANP, BNP, NPR-1, and AQP1 and that BNP is able to modulate AQP1 expression.

The observed expression of NPs and NPR-1 suggests an autocrine and/or paracrine function for these molecules and indicates important roles for NPs in several biological functions, including regulation of fluid movement across the airway epithelial cells, bronchial relaxation [37], vasodilatation, and pulmonary vascular permeability. About the former 


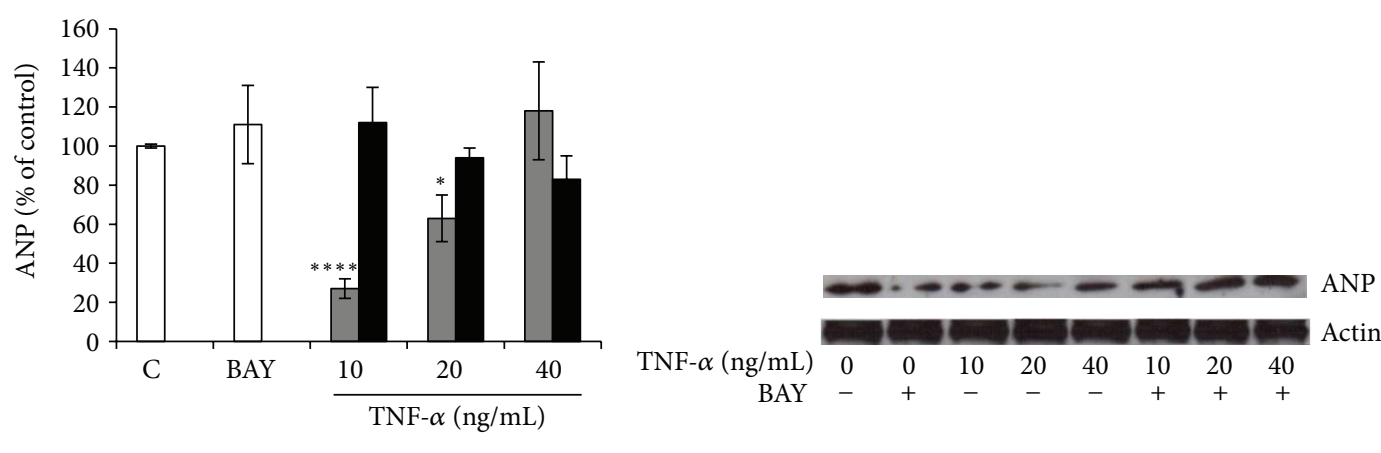

- TNF- $\alpha$

- TNF- $\alpha+$ BAY

(a)

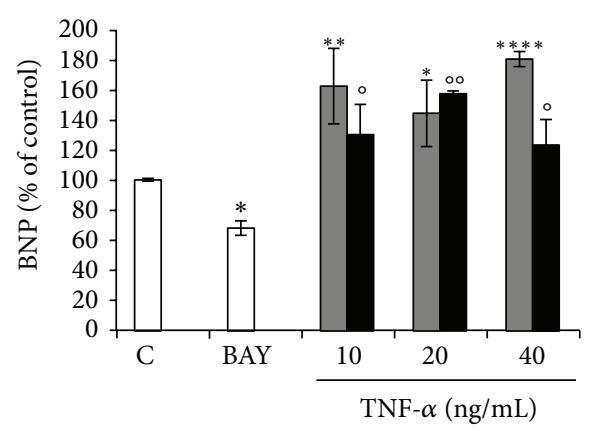

TNF- $\alpha$

- TNF- $\alpha+$ BAY

(c) (b)

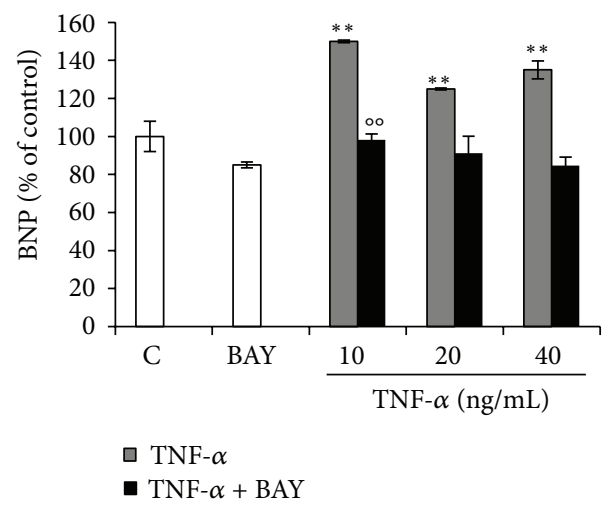

(d)

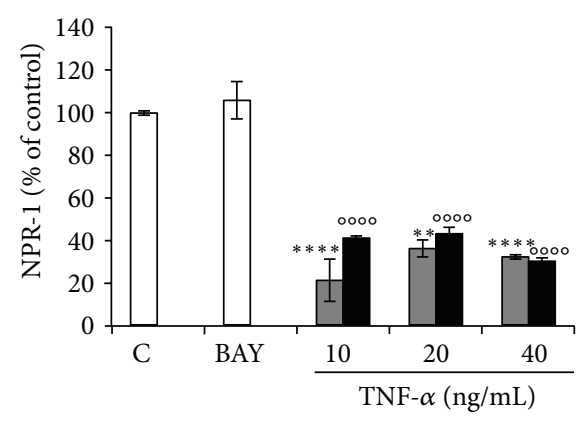

$\square$ TNF- $\alpha$

- TNF- $\alpha+$ BAY

(e)

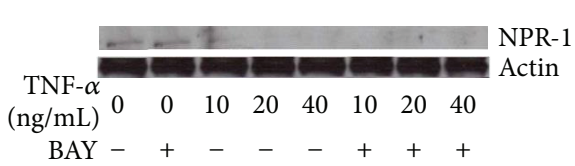

(f)

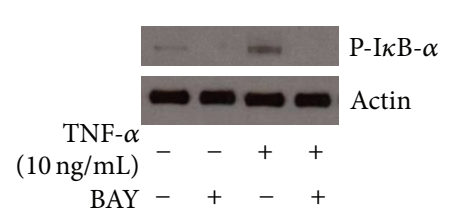

(g)

FIGURE 3: TNF- $\alpha$ modulation of NPs and NPR-1 may require activation of NF- $\kappa$ B pathway. BEAS-2B cells were treated with 10,20 , and $40 \mathrm{ng} / \mathrm{mL}$ TNF- $\alpha$ alone or in combination with NF- $\kappa$ B inhibitor BAY 11-7082 (1 $\mu \mathrm{M})$, for $24 \mathrm{~h}$. ((a), (b)) ANP, ((c), (d)) BNP, ((e), (f)) NPR-1 gene expression at mRNA ((a), (c), and (e)) and protein level ((b), (d), (f)), and (g) Phospho-I $\kappa$ B- $\alpha$ protein level. Western blots were obtained by using the specific rabbit polyclonal or monoclonal Abs. The blots were stripped of the bound $\mathrm{Ab}$ and reprobed with mouse anti- $\beta$-actin, to confirm equal loading. Western blots are representative of three separate experiments. All histograms indicate means \pm SD of three different cultures each of one tested in quadruplicate and expressed as percentage of control $\left({ }^{*} P<0.05,{ }^{* *} P<0.01,{ }^{* * * *} P<0.0001\right.$ versus Controls). $\left({ }^{\circ} \mathrm{P}<0.05,{ }^{\circ 0} \mathrm{P}<0.01\right.$, and ${ }^{\circ 000} \mathrm{P}<0.0001$ versus BAY). C: Controls (untreated cells).

process, the role of ANP and BNP could be analogous to that hypothesized for NPs in transepithelial ion flux in the choroid plexus [38], in the kidney [39], colon [40], and retina [41].

The observed TNF- $\alpha$ capability of selectively regulating ANP, BNP, and NPR-1 gene expression in BEAS-2B cell line is of particular interest because it demonstrates that inflammation alters NPs expression levels. In particular, the significant up-regulation of BNP expression and protein secretion after TNF- $\alpha$ treatment shows that this modulation can occur independently of hemodynamic influences and that inflammation should be considered an extracardiac cause of BNP elevation. Besides, in vitro studies conducted in 


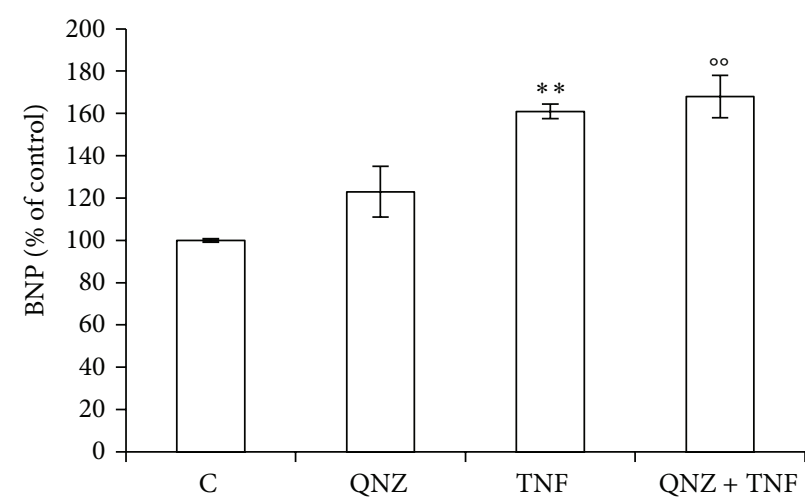

(a)

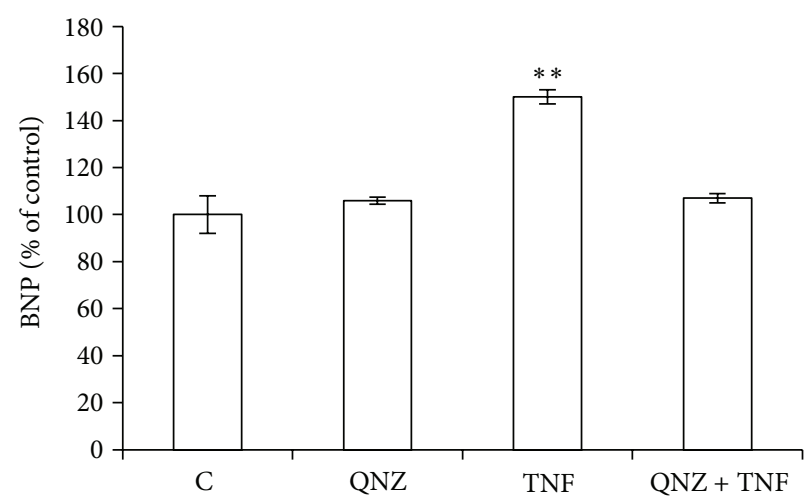

(b)

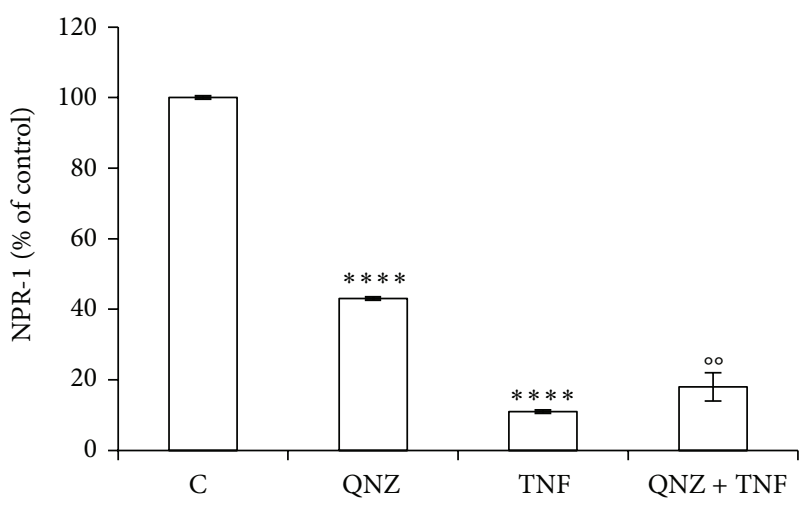

(c)

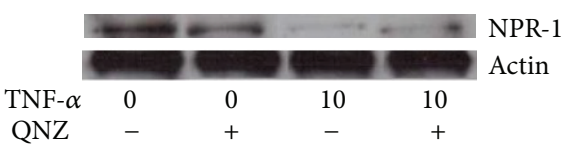

(d)

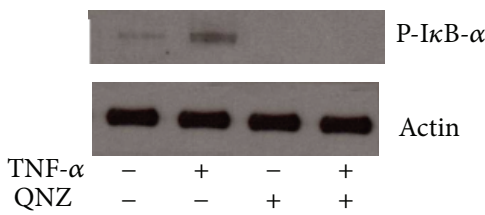

(e)

FIGURE 4: TNF- $\alpha$ modulation of protein levels of BNP and NPR-1 may require activation of NF- $\kappa$ B pathway. BEAS-2B cells were treated $10 \mathrm{ng} / \mathrm{mL}$ TNF- $\alpha$ alone or in combination with the inhibitor QNZ $(10 \mu \mathrm{M})$, for $24 \mathrm{~h}$. ((a), (b)) BNP, ((c), (d)) NPR-1 gene expression at mRNA $((\mathrm{a}),(\mathrm{c}))$ and protein $((\mathrm{b}),(\mathrm{d}))$ level, and (e) Phospho-I $\kappa \mathrm{B}-\alpha$ protein level. Western blots were obtained by using the specific rabbit polyclonal or monoclonal Abs. The blots were stripped of the bound $\mathrm{Ab}$ and reprobed with mouse anti- $\beta$-actin, to confirm equal loading. Western blots are representative of three separate experiments. All histograms indicate means \pm SD of three different cultures each one tested in quadruplicate and expressed as percentage of control $\left({ }^{* *} P<0.01\right.$, and ${ }^{* * * *} P<0.0001$ versus Controls). $\left({ }^{\circ} P<0.01\right.$ versus QNZ). C: Controls (untreated cells).

rat cardiomyocytes have shown that not only hemodynamic factors, but also neurohumoral factors, activated during heart failure, such as angiotensin II, endothelin and cytokines, cause BNP secretion [42-44]. In addition, in patients with cardiovascular diseases, plasma BNP levels have been shown to be also affected by low-grade inflammation [24] and a selective increase in BNP plasma levels has been proposed as a general feature of inflammation [19]. The lack on any apparent TNF- $\alpha$ dose-depending increase in BNP gene expression that we observed in our system could be due to an autocrine negative feedback action mediated by BNP itself, following binding to the NPR-1 receptor expressed in BEAS-2B cells.

The biological role of BNPup-regulation after TNF$\alpha$ treatment remains to be elucidated. However, since it has been demonstrated that BNP regulates the production of major inflammatory molecules, such as IL-12, IL-10, leukotriene B, and prostaglandin E2 in human macrophages [45] and that BEAS-2B are able to release inflammatory molecules [46], it could be reasonable to assume that the observed BNP increase, after TNF- $\alpha$ treatment, may stimulate the production and release of such cytokines also from human epithelial bronchial cells. In addition, in in vitro studies, a potent BNP inhibitory action on the production of the glucocorticoid anti-inflammatory hormone cortisol has been described [47]. Therefore, BNP could be considered a proinflammatory molecule by inducing cytokines expression in target cells and inhibiting the production of anti-inflammatory hormones. Therefore, the observed BNP 


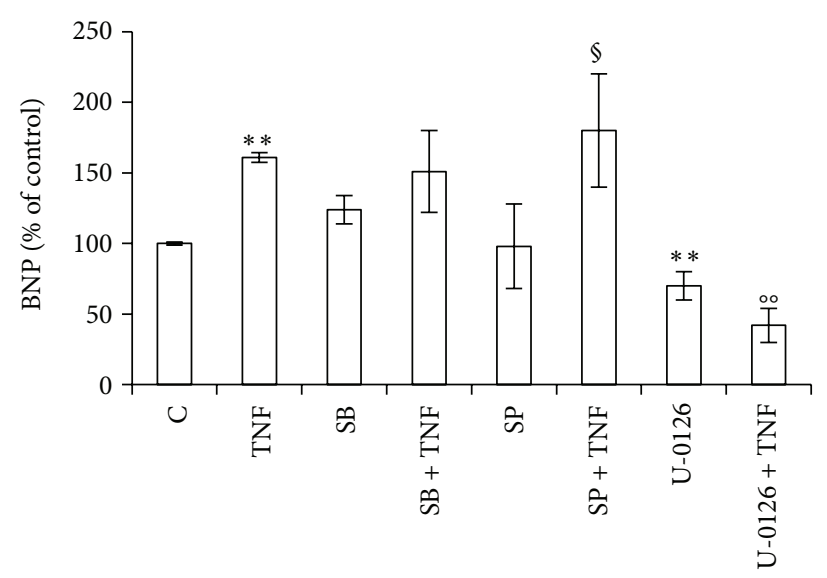

(a)

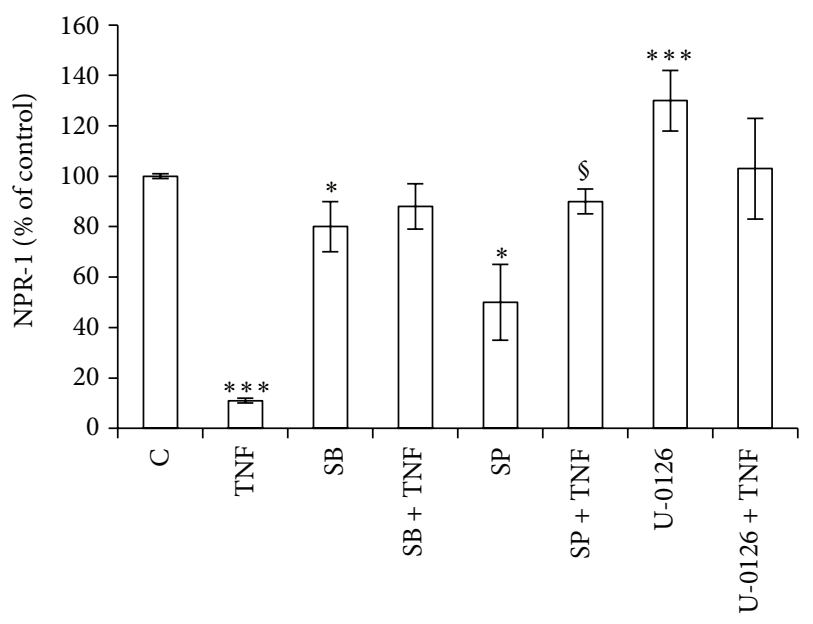

(c)

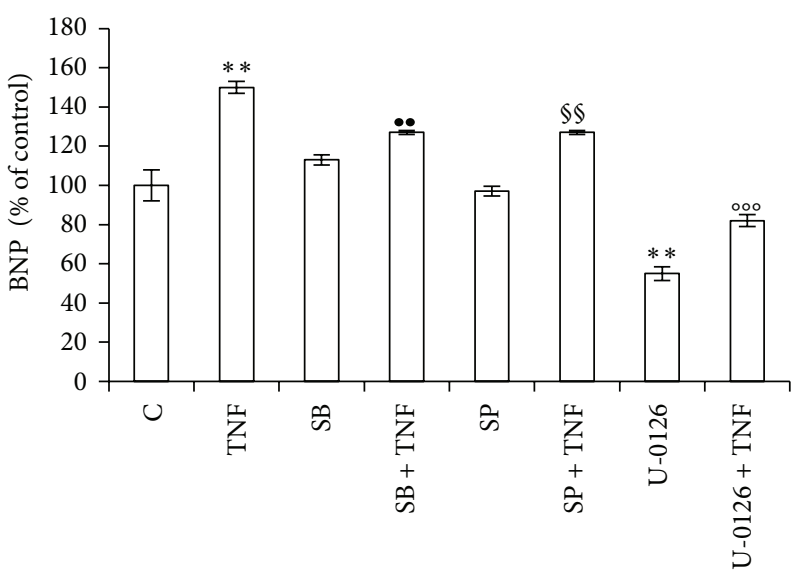

(b)

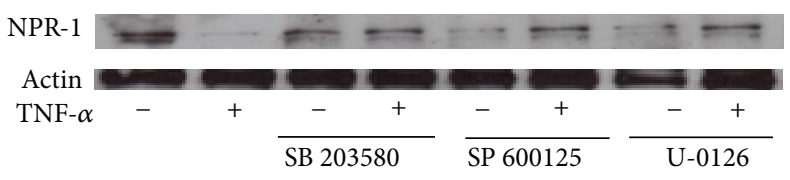

(d)

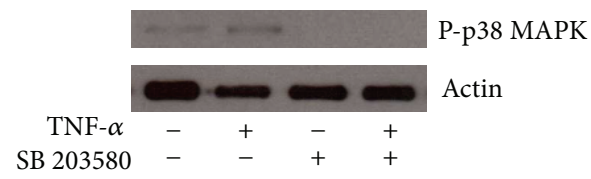

(e)

FIGURE 5: TNF- $\alpha$ modulation of BNP and NPR-1 expression may require activation of MAPKs pathway. BEAS-2B cells were treated with $10 \mathrm{ng} / \mathrm{mL}$ TNF- $\alpha$ alone or in combination with $10 \mu \mathrm{M}$ SB 203580 (p38 MAPK inhibitor), SP 600125 (JNK 1/2 inhibitor), or U-0126 (ERK 1/2 inhibitor), for $24 \mathrm{~h}$. Panels show: ((a), (b)) BNP, ((c), (d)) NPR-1 gene expression at mRNA ((a), (c)) and protein ((b), (d)) level, and (e) Phospho-p38 MAPK protein level. Western blots were obtained by using the specific rabbit polyclonal or monoclonal Abs. The blots were stripped of the bound $\mathrm{Ab}$ and reprobed with mouse anti- $\beta$-actin, to confirm equal loading. Western blots are representative of three separate experiments. All histograms indicate means \pm SD of three different cultures each one tested in quadruplicate and expressed as percentage of control. $\left({ }^{*} P<0.05,{ }^{* *} P<0.01\right.$, and ${ }^{* * *} P<0.001$ versus Controls $)\left({ }^{*} P<0.01\right.$ versus $\left.\mathrm{SB}\right)\left({ }^{\S} P<0.05,{ }^{\S \S} \mathrm{P}<0.01\right.$ versus SP) $\left({ }^{\circ} \mathrm{P}<0.01\right.$, ${ }^{\circ 0} P<0.001$ versus U-0126). C: Controls (untreated cells).

up-regulation after TNF- $\alpha$ treatment could concur in potentiating an inflammatory status. The increased production and release of specific cytokines, causing systemic changes known as the acute phase response $[5,8,10]$, induced by TNF- $\alpha$, may thus also occur via BNP up-regulation.

Recently, a BNP rise has been observed in patients undergoing pulmonary lobectomy for lung cancer [11]. In particular, the patients, none of whom developed signs or symptoms of heart failure during the postoperative period, showed an early significant increase, on day 1, immediately after surgery, of the plasma concentrations of BNP which was followed on the postoperative day 2 by a significant weight gain correlated with large volumes of fluids accumulation, despite a negative intraoperative fluid balance and peroperative strict fluid restriction [11]. We suggest that such an increase could be, at least in part, explained by the ability of proinflammatory cytokines, such as TNF- $\alpha$, to upregulate BNP gene expression and secretion, and that this 


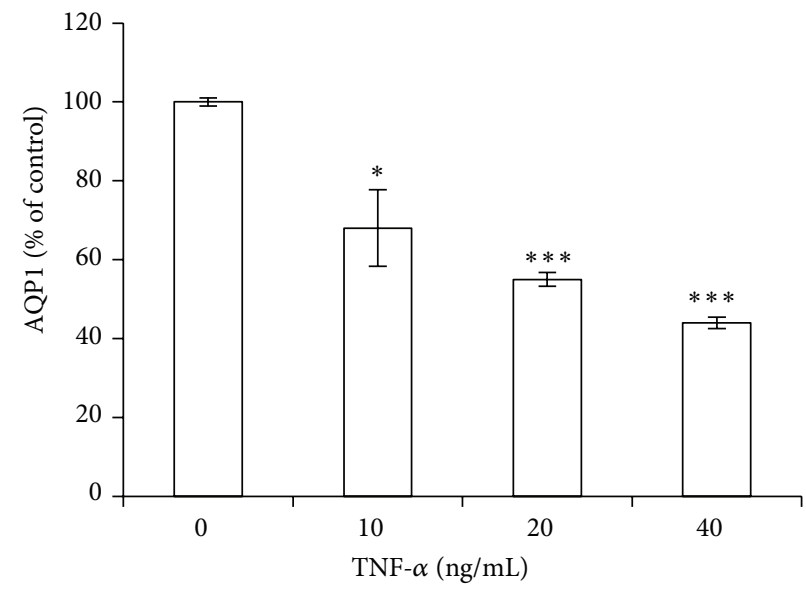

(a)

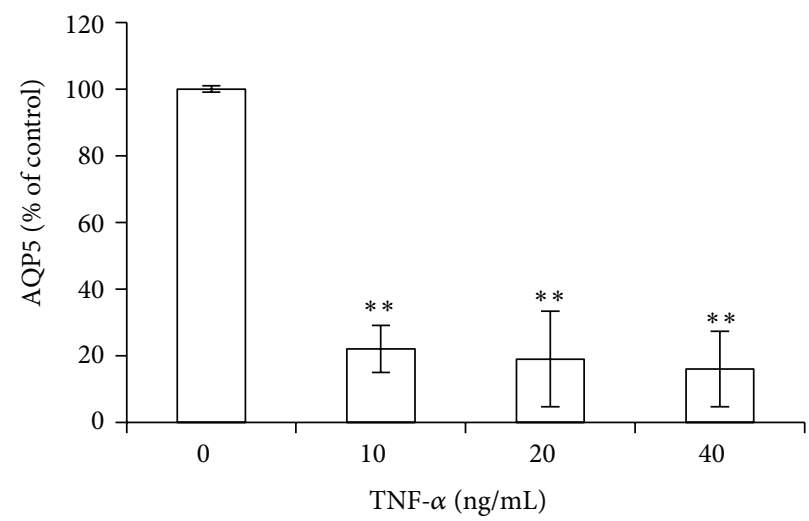

(c)

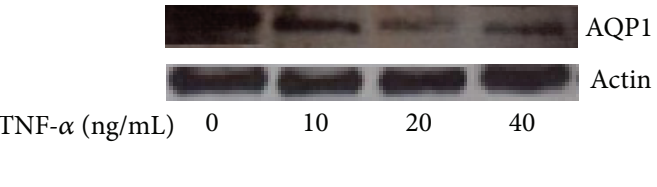

(b)

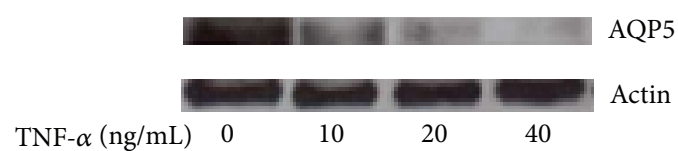

(d)

Figure 6: TNF- $\alpha$ decreases AQP1 and AQP5 expression in BEAS 2B cells. BEAS-2B cells were treated with 10, 20, and $40 \mathrm{ng} / \mathrm{mL}$ TNF- $\alpha$ for $24 \mathrm{~h}$. Gene expression of AQP1 ((a), (b)) and AQP5 ((c), (d)) at mRNA ((a), (c)) and protein ((b), (d)) level. Western blots were obtained by using the specific rabbit polyclonal Abs. The blots were stripped of the bound $\mathrm{Ab}$ and reprobed with mouse anti- $\beta$-actin, to confirm equal loading. Western blots are representative of three separate experiments. All histograms indicate means \pm SD of three different cultures each one tested in quadruplicate and expressed as percentage of control $\left({ }^{*} P<0.01,{ }^{* *} P<0.001\right.$, and ${ }^{* * *} P<0.0001$ versus untreated cells).

up-regulation could enhance the major surgery-related early hyperinflammatory response, essential for tissue repair and host defense [5].

The observed dexamethasone capability to completely revert TNF- $\alpha$-induced BNP up-regulation suggests that this anti-inflammatory glucocorticoid may prevent BNP-related effects.

Regarding ANP, the observed significant down-regulation of mRNA and protein levels after 10, $20 \mathrm{ng} / \mathrm{mL}$ TNF- $\alpha$ treatment suggests that also this condition could affect local inflammation status. In fact, ANP administration determines anti-inflammatory effects in airway epithelial cells [48], playing important roles in modulating inflammatory response. In consideration of such ANP anti-inflammatory action, we speculate that the observed TNF- $\alpha$-induced ANP downregulation could concur in enhancing an inflammatory status. Differently from the above reported doses, $40 \mathrm{ng} / \mathrm{mL}$ TNF- $\alpha$ administration induced ANP up-regulation, even though not statistically significant. We suggest that this result might be due to a direct BNP involvement. In fact, a marked ANP up-regulation was observed after BNP treatment at the dose accumulated in culture medium after $40 \mathrm{ng} / \mathrm{mL}$ TNF- $\alpha$ treatment.

The observed selective modulation in ANP and BNP gene expression after TNF- $\alpha$ treatment, in line with other studies in different cell models $[19,49,50]$ could be related to a different regulation mechanism at transcriptional level, as suggested by our observation on the different involvement of NF- $\kappa \mathrm{B}$ and MAPKs signaling pathways. In particular, we demonstrated that ANP down-regulation, TNF- $\alpha$-mediated, occurs via NF- $\kappa$ B activation pathway, whereas BNP modulation requires ERK $1 / 2$ activation pathway. NF- $\kappa$ B involvement in TNF- $\alpha$-induced ANP down-regulation is not opposed to the proinflammatory role of this transcription factor, being ANP a molecule that exerts an anti-inflammatory effect in airway epithelial cells [48]. Regarding the mechanism linking $\mathrm{NF}-\kappa \mathrm{B}$ to the downregulation of ANP gene expression, we suggest that it could be similar to that recently proposed for Fibroblast Growth Factor 10 (FGF-10), where NF- $\kappa$ B activation may lead to reduced gene expression, by recruiting inhibitory factors to specific gene promoters [51]. 


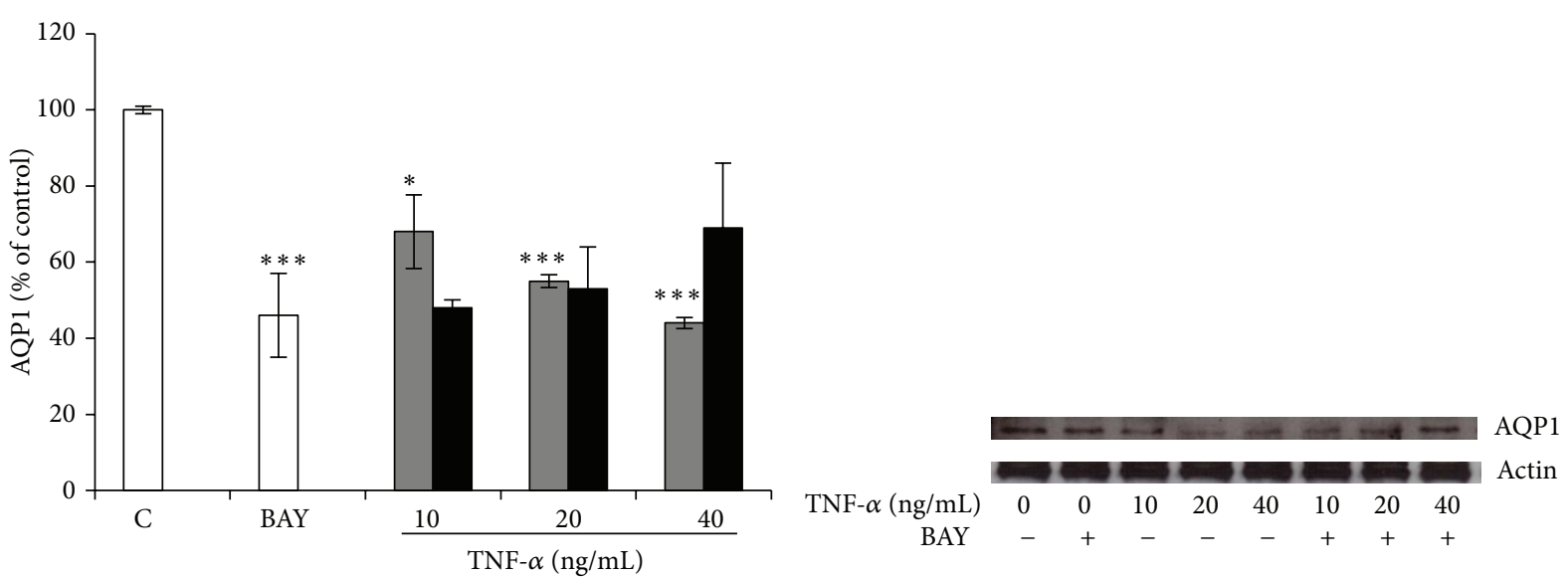

TNF- $\alpha$

- TNF- $\alpha+$ BAY

(a)

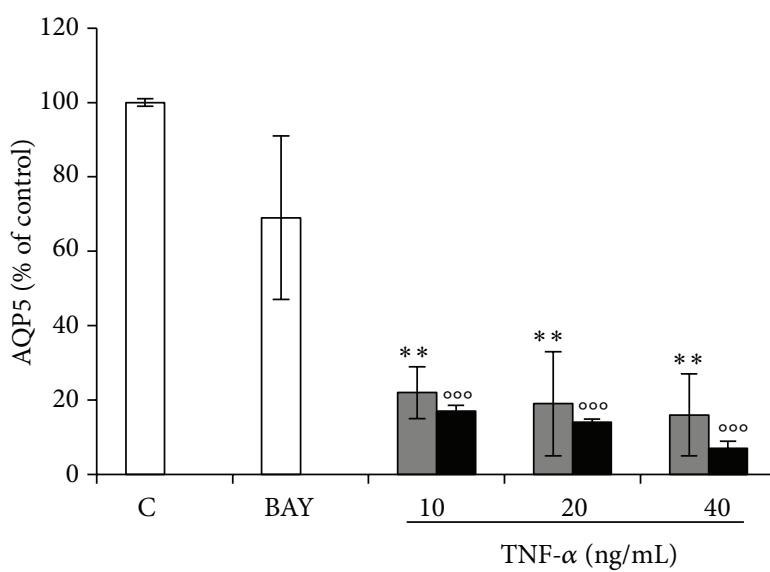

$\square$ TNF- $\alpha$

TNF- $\alpha+$ BAY (b)

(c)

(d)

FIGURE 7: TNF- $\alpha$ downregulation of AQP1 and AQP5 expression may require activation of NF- $\kappa$ B pathway.BEAS-2B cells were treated with 10,20 , and $40 \mathrm{ng} / \mathrm{mL}$ TNF- $\alpha$ alone or in combination with NF- $\kappa$ B inhibitor BAY 11-7082 $(1 \mu \mathrm{M})$, for $24 \mathrm{~h}$. Gene expression of AQP1 ((a), (b)) and AQP5 ((c), (d)) at mRNA ((a), (c)) and protein ((b), (d)) level. Western blots were obtained by using the specific rabbit polyclonal Abs. The blots were stripped of the bound $\mathrm{Ab}$ and reprobed with mouse anti- $\beta$-actin, to confirm equal loading. Western blots are representative of three separate experiments. All histograms indicate means \pm SD of three different cultures each one tested in quadruplicate and expressed as percentage of control $\left({ }^{*} P<0.01,{ }^{* *} P<0.001,{ }^{* * *} P<0.0001\right.$ versus Controls; and ${ }^{\circ 00} P<0.0001$ versus BAY). C: Controls (untreated cells).

ANP and BNP biological functions occur through their binding to the same NPR-1 [13]. Here, we demonstrated, for the first time to our knowledge, TNF- $\alpha$ capability to downregulate NPR-1 mRNA and protein expression in BEAS$2 \mathrm{~B}$ cells and that this regulation occurs via MAPKs signaling pathway activation. The consequence of the complex TNF$\alpha$-induced NPs and NPR-1 observed modulation, associated with their binding to the same receptor on BEAS-2B cells, makes it difficult to predict what would be the net resulting effect both in vitro and in vivo, in relation also to the presence of a possible autocrine regulation by NPs and/or to the effects of different cytokines activated by both BNP and TNF- $\alpha$. We hypothesize that the TNF- $\alpha$-induced downregulation of
NPR-1, paralleled by an up-regulation of BNP, could also lead to a paracrine action of this peptide, possibly on the microvascular endothelium of the lung, where NPR-1 is densely expressed [18]. In this context, we speculate that the induction of local modification on BNP or ANP by TNF- $\alpha$ in human bronchial epithelial cells could alter the barrier permeability of the pulmonary microcirculation. Hence, TNF$\alpha$, acting on epithelial cells, could also indirectly contribute to endothelial cells barrier dysfunction and permeability, by enhancing the local production of proinflammatory BNP and by down-regulating the anti-inflammatory expression of ANP. Besides, exogenous synthetic ANP has been shown to protect from endothelial barrier dysfunction in in vivo 


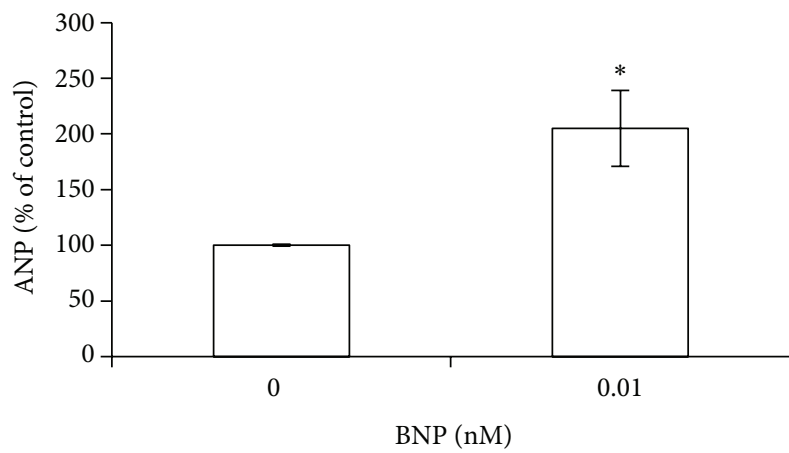

(a)

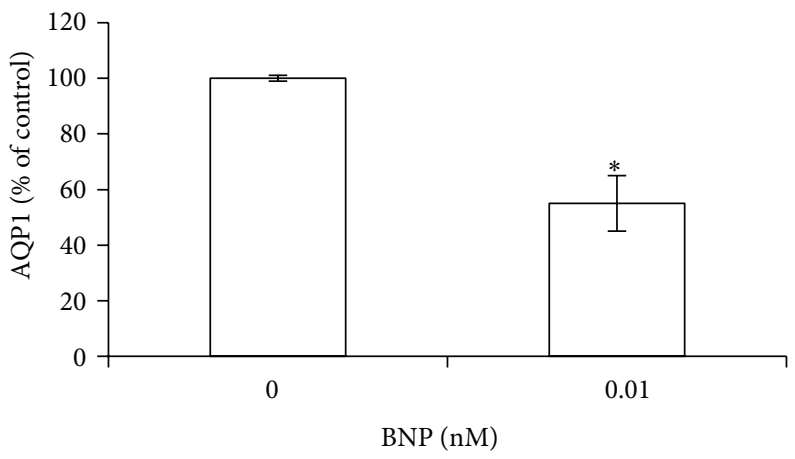

(c)

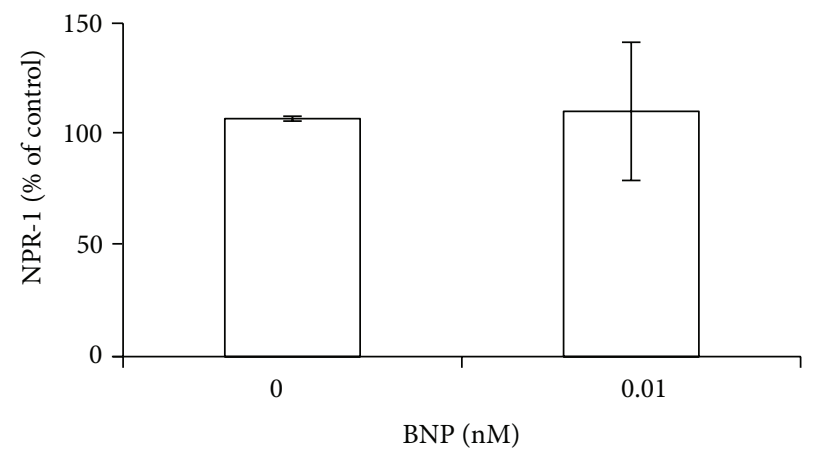

(b)

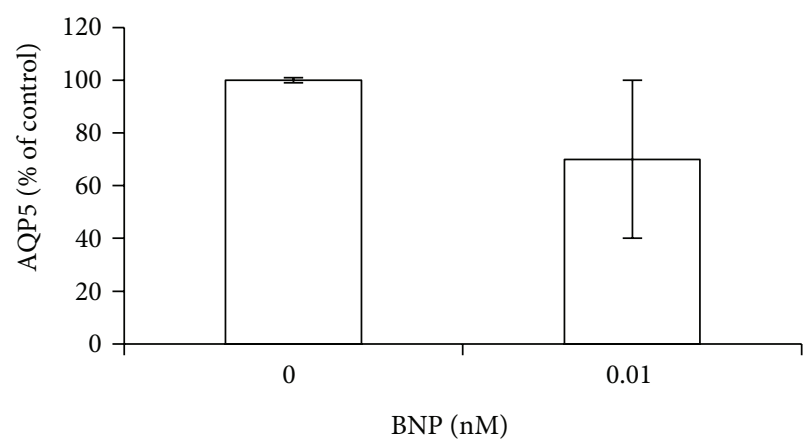

(d)

Figure 8: BNP effect on ANP, NPR-1, AQP1, and AQP5 expression.BEAS-2B cells were treated with $0.01 \mathrm{nM}$ BNP for $24 \mathrm{~h}$. Histograms show (a) ANP, (b) NPR-1, (c) AQP1, and (d) AQP5 gene expression at mRNA level. All histograms indicate means \pm SD of three different cultures each one tested in quadruplicate and expressed as percentage of control $\left({ }^{*} \mathrm{P}<0.05\right.$ versus untreated cells).

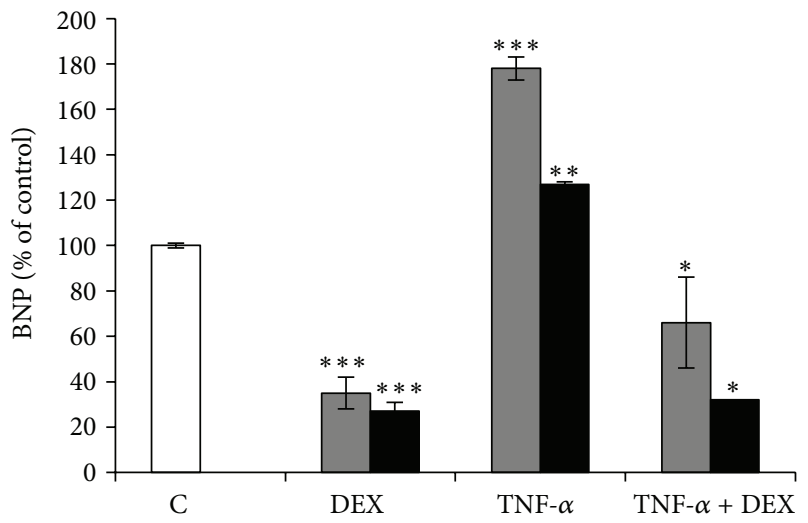

Figure 9: Dexamethasone effect on BNP expression. BEAS-2B cells were treated with $1 \mu \mathrm{M}$ dexamethasone (DEX) and $40 \mathrm{ng} / \mathrm{mL}$ TNF- $\alpha$ alone or in combination with DEX, for $24 \mathrm{~h}$. Histograms show BNP gene expression at mRNA (gray bars) and protein (black bars) level. All histograms indicate means \pm SD of three different cultures each one tested in quadruplicate and expressed as percentage of control $\left({ }^{*} P<0.01,{ }^{* *} P<0.001\right.$, and ${ }^{* * *} P<0.0001$ versus Controls). C: Controls (untreated cells).

and in vitro models of lung injury [18] and the therapeutical relevance of these experimental observations has been shown in intensive care patients without heart disease, where intravenous ANP infusion diminished pulmonary vascular permeability and pulmonary edema [18].
Regarding AQPs, we demonstrated that BEAS-2B cells express AQP1 and AQP5 and that TNF- $\alpha$ directly downregulates their expression at mRNA and protein levels. Regarding AQP1, also an additional BNP-mediated TNF- $\alpha$ involvement can be proposed. In fact, AQP1 down-regulation was observed with BNP treatment at the dose accumulated in culture medium after $40 \mathrm{ng} / \mathrm{mL}$ TNF- $\alpha$ treatment. The mechanisms that underlie AQPs regulation are of considerable interest. Several AQPs has recently been demonstrated to undergo complex regulation [27]. Our results show that AQP1 and APQ5 are subject to inflammation regulation, adding an important piece of information in this context. Our results are in agreement with other studies, describing a marked reduction in the expression levels of AQP1 and AQP5 in mouse lung [30] and mouse lung epithelial cells [31]. The biological significance of the observed TNF- $\alpha$-induced AQP1 and AQP5 down-regulation is, at present, unclear. It has been recently suggested that the decrease in both AQPs may play an important role in the development of lung edema [52], which is known to be related with fluid retention. We, therefore, speculate that TNF- $\alpha$-induced AQP1 and AQP5 down-regulation might play a role also in the excess of fluid accumulation, related to major surgical procedures.

\section{Conclusions}

In conclusion, our results provided evidence that, in human bronchial epithelial cells BEAS-2B, TNF- $\alpha$ selectively modulates mRNA and protein expression levels of different 
molecules involved in body fluid homeostasis: ANP, BNP, and their receptor NPR-1, AQP1, and AQP5. Moreover, our data pointed out that the changes, specifically affecting NPs expression, occur independently from hemodynamic influences and that inflammation should be considered an extracardiac cause of BNP elevation, adding an important piece of information in the novel area of study regarding NPs and inflammation. In addition, we demonstrated that such a modulation occurs via different involvement of NK- $\kappa \mathrm{B}$ and MAPKs signaling pathways. Finally, we suggested inflammation among the mechanisms involved in the regulation of AQP1 and AQP5. Therefore, in this exploratory study, we speculate that TNF- $\alpha$ might be involved in postoperativefluid retention related to major surgery.

\section{Conflict of Interests}

The authors declare that there is no conflict of interests.

\section{Acknowledgment}

The authors thank Mrs. Roberta Frosini for the excellent technical assistance.

\section{References}

[1] E. Itobi, M. Stroud, and M. Elia, "Impact of oedema on recovery after major abdominal surgery and potential value of multifrequency bioimpedance measurements," The British Journal of Surgery, vol. 93, no. 3, pp. 354-361, 2006.

[2] J. A. Lowell, C. Schifferdecker, D. F. Driscoll, P. N. Benotti, and B. R. Bistrian, "Postoperative fluid overload: not a benign problem," Critical Care Medicine, vol. 18, no. 7, pp. 728-733, 1990.

[3] A. M. Møller, T. Pedersen, P.-E. Svendsen, and A. Engquist, "Perioperative risk factors in elective pneumonectomy: the impact of excess fluid balance," European Journal of Anaesthesiology, vol. 19, no. 1, pp. 57-62, 2002.

[4] E. Bennett-Guerrero, D. E. Feierman, G. R. Barclay et al., "Preoperative and intraoperative predictors of postoperative morbidity, poor graft function, and early rejection in 190 patients undergoing liver transplantation," Archives of Surgery, vol. 136, no. 10, pp. 1177-1183, 2001.

[5] J. P. Desborough, "The stress response to trauma and surgery," The British Journal of Anaesthesia, vol. 85, no. 1, pp. 109-117, 2000.

[6] H. Tsujimoto, S. Ono, T. Majima et al., "Differential toll-like receptor expression after ex vivo lipopolysaccharide exposure in patients with sepsis and following surgical stress," Clinical Immunology, vol. 119, no. 2, pp. 180-187, 2006.

[7] C. Evans, C. Galustian, D. Kumar et al., "Impact of surgery on immunologic function: comparison between minimally invasive techniques and conventional laparotomy for surgical resection of colorectal tumors," The American Journal of Surgery, vol. 197, no. 2, pp. 238-245, 2009.

[8] F. Catena, L. Ansaloni, A. Avanzolini et al., "Systemic cytokine response after emergency and elective surgery for colorectal carcinoma," International Journal of Colorectal Disease, vol. 24, no. 7, pp. 803-808, 2009.
[9] R. Sarbinowski, S. Arvidsson, M. Tylman, T. Öresland, and A. Bengtsson, "Plasma concentration of procalcitonin and systemic inflammatory response syndrome after colorectal surgery," Acta Anaesthesiologica Scandinavica, vol. 49, no. 2, pp. 191-196, 2005.

[10] P. Sheeran and G. M. Hall, "Cytokines in anaesthesia," The British Journal of Anaesthesia, vol. 78, no. 2, pp. 201-219, 1997.

[11] L. Cagini, R. Capozzi, V. Tassi et al., "Fluid and electrolyte balance after major thoracic surgery by bioimpedance and endocrine evaluation," European Journal of Cardio-Thoracic Surgery, vol. 40, no. 2, pp. e71-e76, 2011.

[12] T. Omland and T. Hagve, "Natriuretic peptides: physiologic and analytic considerations," Heart Failure Clinics, vol. 5, no. 4, pp. 471-487, 2009.

[13] L. R. Potter, A. R. Yoder, D. R. Flora, L. K. Antos, and D. M. Dickey, "Natriuretic peptides: their structures, receptors, physiologic functions and therapeutic applications," Handbook of Experimental Pharmacology, vol. 191, pp. 341-366, 2009.

[14] T. G. Flynn, M. L. de Bold, and A. J. de Bold, "The amino acid sequence of an atrial peptide with potent diuretic and natriuretic properties," Biochemical and Biophysical Research Communications, vol. 117, no. 3, pp. 859-865, 1983.

[15] A. J. de Bold, "Atrial natriuretic factor: a hormone produced by the heart," Science, vol. 230, pp. 767-770, 1985.

[16] K. Kangawa, Y. Tawaragi, S. Oikawa et al., "Identification of rat $\gamma$ atrial natriuretic polypeptide and characterization of the cDNA encoding its precursor," Nature, vol. 312, no. 5990, pp. 152-155, 1984.

[17] T. Sudoh, K. Kangawa, N. Minamino, and H. Matsuo, "A new natriuretic peptide in porcine brain," Nature, vol. 332, no. 6159, pp. 78-81, 1988.

[18] M. Kuhn, "Endothelial actions of atrial and B-type natriuretic peptides," The British Journal of Pharmacology, vol. 166, no. 2, pp. 522-531, 2012.

[19] A. J. de Bold, "Cardiac natriuretic peptides gene expression and secretion in inflammation," Journal of Investigative Medicine, vol. 57, pp. 29-32, 2009.

[20] S. P. D'Souza, M. Davis, and G. F. Baxter, "Autocrine and paracrine actions of natriuretic peptides in the heart," Pharmacology and Therapeutics, vol. 101, no. 2, pp. 113-129, 2004.

[21] M. Brueckmann, G. Huhle, S. Lang et al., "Prognostic value of plasma N-terminal pro-brain natriuretic peptide in patients with severe sepsis," Circulation, vol. 112, no. 4, pp. 527-534, 2005.

[22] J. Charpentier, C. E. Luyt, Y. Fulla et al., "Brain natriuretic peptide: a marker of myocardial dysfunction and prognosis during severe sepsis," Critical Care Medicine, vol. 32, no. 3, pp. 660-665, 2004.

[23] R. Shor, Y. Rozenman, A. Bolshinsky et al., "BNP in septic patients without systolic myocardial dysfunction," European Journal of Internal Medicine, vol. 17, no. 8, pp. 536-540, 2006.

[24] T. Inoue, M. Kawai, T. Nakane et al., "Influence of low-grade inflammation on plasma B-type natriuretic peptide levels," Internal Medicine, vol. 49, no. 24, pp. 2659-2668, 2010.

[25] P. Agre, L. S. King, M. Yasui et al., "Aquaporin water channelsfrom atomic structure to clinical medicine," Journal of Physiology, vol. 542, no. 1, pp. 3-16, 2002.

[26] P. Agre and D. Kozono, "Aquaporin water channels: molecular mechanisms for human diseases," FEBS Letters, vol. 555, no. 1, pp. 72-78, 2003. 
[27] J. M. Carbrey and P. Agre, "Discovery of the aquaporins and development of the field," Handbook of Experimental Pharmacology, vol. 190, pp. 3-28, 2009.

[28] O. Bloch and G. T. Manley, "The role of aquaporin-4 in cerebral water transport and edema," Neurosurgical Focus, vol. 22, no. 5, article E3, 2007.

[29] J. Li, M. Xu, Q. Fan et al., "Tanshinone IIA ameliorates seawater exposure-induced lung injury by inhibiting aquaporins (AQP) 1 and AQP5 expression in lung," Respiratory Physiology and Neurobiology, vol. 176, no. 1-2, pp. 39-49, 2011.

[30] J. E. Towne, K. S. Harrod, C. M. Krane, and A. G. Menon, "Decreased expression of aquaporin (AQP)1 and AQP5 in mouse lung after acute viral infection," The American Journal of Respiratory Cell and Molecular Biology, vol. 22, no. 1, pp. 34-44, 2000.

[31] J. E. Towne, C. M. Krane, C. J. Bachurski, and A. G. Menon, "Tumor necrosis factor- $\alpha$ inhibits aquaporin 5 expression in mouse lung epithelial cells," The Journal of Biological Chemistry, vol. 276, no. 22, pp. 18657-18664, 2001.

[32] K. J. Livak and T. D. Schmittgen, "Analysis of relative gene expression data using real-time quantitative PCR and the 2$\Delta \Delta$ CT method," Methods, vol. 25, no. 4, pp. 402-408, 2001.

[33] K. Verhelst, I. Carpentier, and R. Beyaert, "Regulation of TNFinduced NF- $\kappa$ B activation by different cytoplasmic ubiquitination events," Cytokine and Growth Factor Reviews, vol. 22, no. 5-6, pp. 277-286, 2011.

[34] L. Qian, Y. Shen, J. C. Chen et al., "3D-QSAR and docking studies of quinazoline derivatives with the inhibatory activity toward NF- $\kappa$ B," QSAR and Combinatorial Science, vol. 27, no. 8, pp. 984-995, 2008.

[35] P. D. N'Guessan, S. Hippenstiel, M. O. Etouem et al., "Streptococcus pneumoniae induced p38 MAPK- and NF- $\kappa \mathrm{B}$-dependent COX-2 expression in human lung epithelium," The American Journal of Physiology - Lung Cellular and Molecular Physiology, vol. 290, no. 6, pp. L1131-L1138, 2006.

[36] B. Schmeck, K. Moog, J. Zahlten et al., "Streptococcus pneumoniae induced c-Jun-N-terminal kinase- and AP-I-dependent IL8 release by lung epithelial BEAS-2B cells," Respiratory Research, vol. 7, article 98, 2006.

[37] M. G. Matera, L. Calzetta, D. Passeri et al., "Epithelium integrity is crucial for the relaxant activity of brain natriuretic peptide in human isolated bronchi," The British Journal of Pharmacology, vol. 163, no. 8, pp. 1740-1754, 2011.

[38] R. Quirion, M. Dalpe, A. de Lean, J. Gutkowska, M. Cantin, and J. Genest, "Atrial natriuretic factor (ANF) binding sites in brain and related structures," Peptides, vol. 5, no. 6, pp. 1167-1172, 1984.

[39] M. B. Pamnani, D. L. Clough, J. S. Chen, W. T. Link, and F. J. Haddy, "Effects of rat atrial extract on sodium transport and blood pressure in the rat," Proceedings of the Society for Experimental Biology and Medicine, vol. 176, no. 2, pp. 123-131, 1984.

[40] T. R. Traynor and S. M. O'Grady, "Brain natriuretic peptide stimulates $\mathrm{K}$ and $\mathrm{Cl}$ secretion across porcine distal colon epithelium," The American Journal of Physiology-Cell Physiology, vol. 260, no. 4, pp. C750-C755, 1991.

[41] R. Rollín, A. Mediero, M. Roldán-Pallarés, A. Fernández-Cruz, and R. Fernández-Durango, "Natriuretic peptide system in the human retina," Molecular Vision, vol. 10, pp. 15-22, 2004.
[42] M. Harada, H. Itoh, O. Nakagawa et al., "Significance of ventricular myocytes and nonmyocytes interaction during cardiocyte hypertrophy: evidence for endothelin-1 as a paracrine hypertrophic factor from cardiac nonmyocytes," Circulation, vol. 96, no. 10, pp. 3737-3744, 1997.

[43] K. Kuwahara, Y. Saito, M. Harada et al., "Involvement of cardiotrophin-1 in cardiac myocyte-nonmyocyte interactions during hypertrophy of rat cardiac myocytes in vitro," Circulation, vol. 100, no. 10, pp. 1116-1124, 1999.

[44] E. Harada, O. Nakagawa, M. Yoshimura et al., "Effect of interleukin- $1 \beta$ on cardiac hypertrophy and production of natriuretic peptides in rat cardiocyte culture," Journal of Molecular and Cellular Cardiology, vol. 31, no. 11, pp. 1997-2006, 1999.

[45] V. Chiurchiù, V. Izzi, F. D’Aquilio, F. Carotenuto, P. Di Nardo, and P. M. Baldini, "Brain natriuretic peptide (BNP) regulates the production of inflammatory mediators in human THP-1 macrophages," Regulatory Peptides, vol. 148, no. 1-3, pp. 26-32, 2008.

[46] N. S. Holden, C. F. Rider, M. J. Bell et al., "Enhancement of inflammatory mediator release by $\beta 2$-adrenoceptor agonists in airway epithelial cells is reversed by glucocorticoid action," The British Journal of Pharmacology, vol. 160, no. 2, pp. 410-420, 2010.

[47] V. S. Fang, C. C. Juan, J. G. S. Won, and L. T. Ho, "Further study of aldosterone secretion-inhibitory factor and brain natriuretic peptide on cortisol production of Guinea pig zona fasciculata cells," Chinese Journal of Physiology, vol. 43, no. 4, pp. 141-147, 2000.

[48] G. Hellermann, X. Kong, J. Gunnarsdóttir et al., "Mechanism of bronchoprotective effects of a novel natriuretic hormone peptide," Journal of Allergy and Clinical Immunology, vol. 113, no. 1, pp. 79-85, 2004.

[49] K. K. Ma, T. Ogawa, and A. J. de Bold, "Selective upregulation of cardiac brain natriuretic peptide at the transcriptional and translational levels by pro-inflammatory cytokines and by conditioned medium derived from mixed lymphocyte reactions via p38 MAP kinase," Journal of Molecular and Cellular Cardiology, vol. 36, no. 4, pp. 505-513, 2004.

[50] T. Ogawa, J. P. Veinot, M. L. K. de Bold, T. Georgalis, and A. J. De Bold, "Angiotensin II receptor antagonism reverts the selective cardiac BNP upregulation and secretion observed in myocarditis," The American Journal of Physiology-Heart and Circulatory Physiology, vol. 294, no. 6, pp. H2596-H2603, 2008.

[51] B. J. Carver, E. J. Plosa, A. M. Stinnett, T. S. Blackwell, and L. S. Prince, "Interactions between NF- $\kappa$ B and SP3 connect inflammatory signaling with reduced FGF-10 expression," The Journal of Biological Chemistry, vol. 288, no. 21, pp. 15318-15325, 2013.

[52] C. Dong, G. Wang, B. Li et al., "Anti-asthmatic agents alleviate pulmonary edema by upregulating AQP1 and AQP5 expression in the lungs of mice with OVA-induced asthma," Respiratory Physiology and Neurobiology, vol. 181, no. 1, pp. 21-28, 2012. 


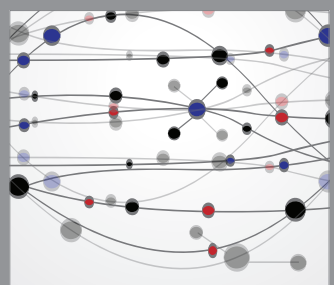

The Scientific World Journal
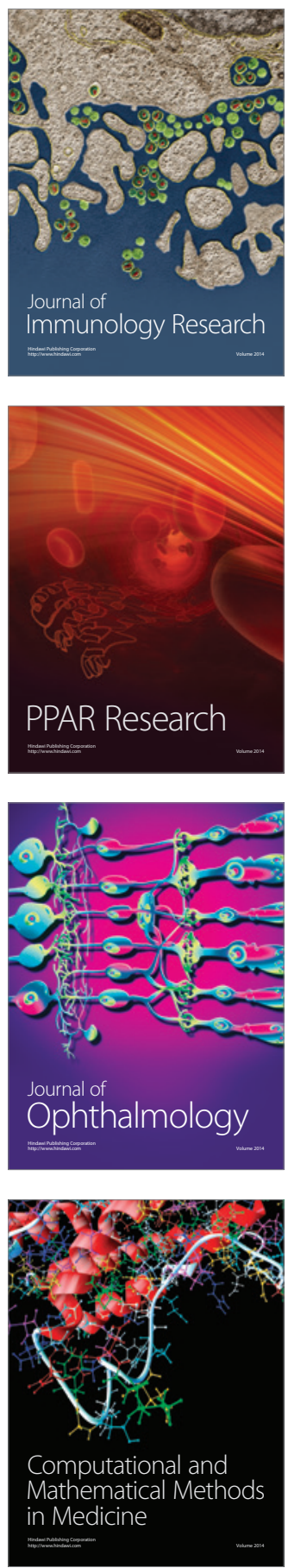

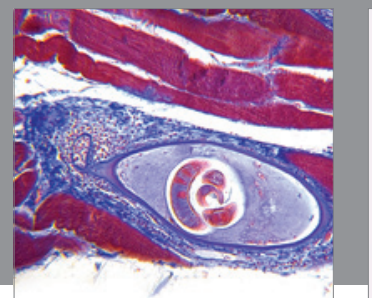

Gastroenterology

Research and Practice
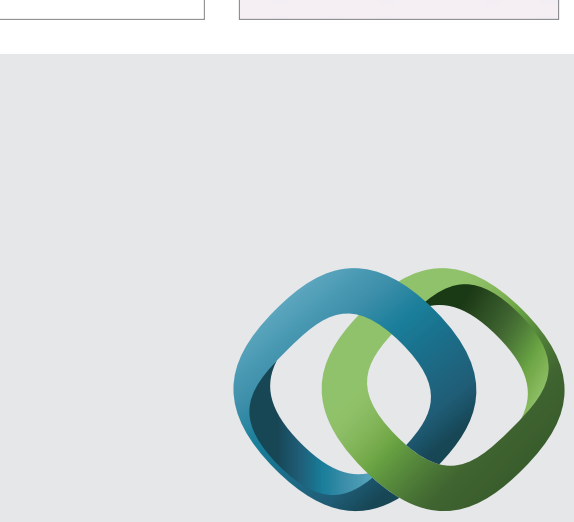

\section{Hindawi}

Submit your manuscripts at

http://www.hindawi.com
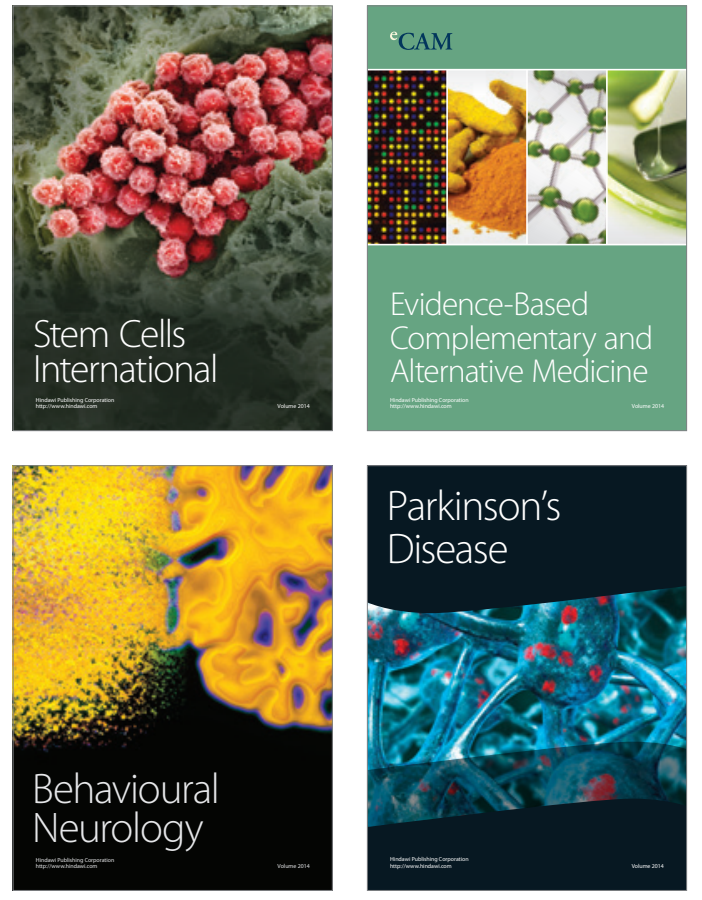
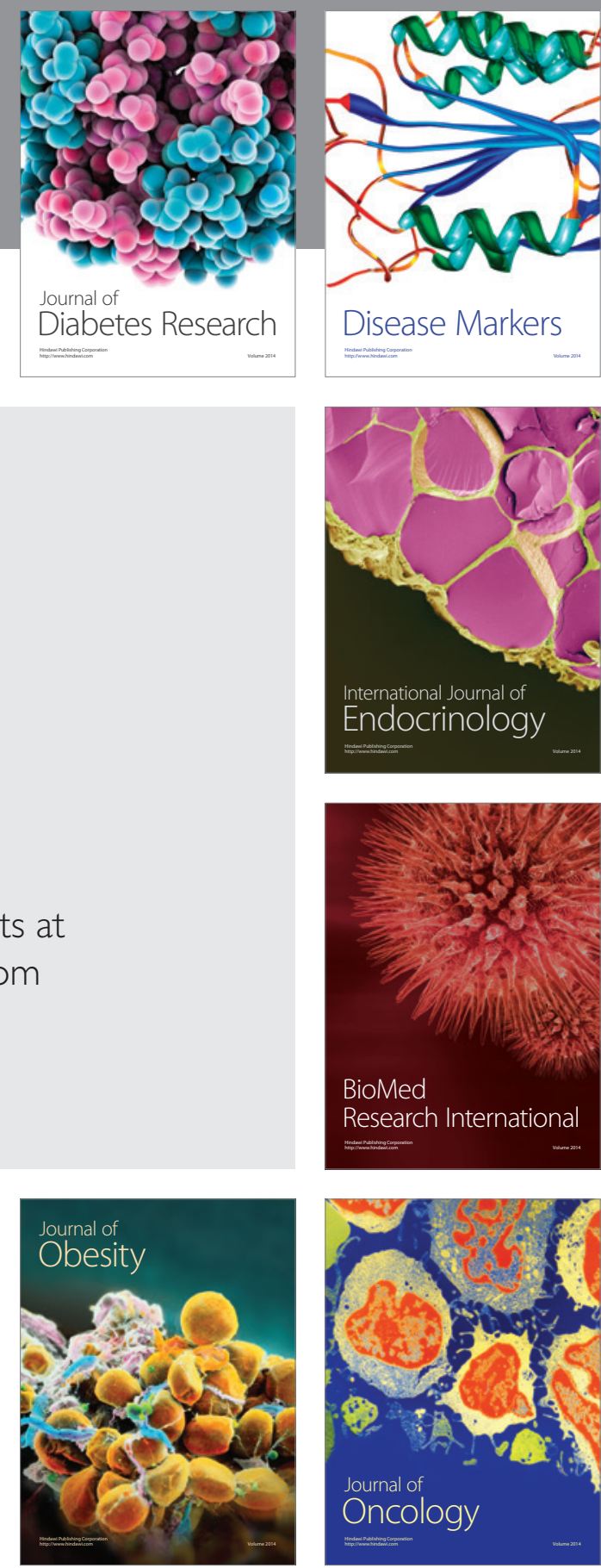

Disease Markers
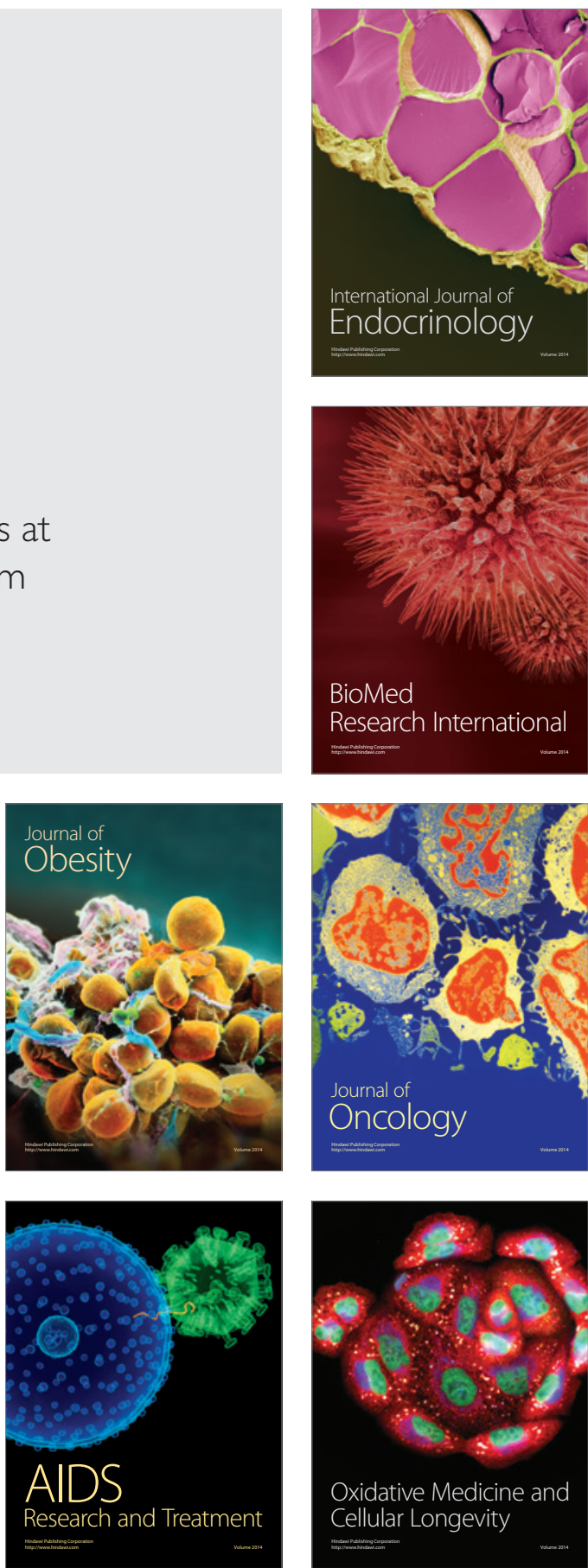